\title{
THE MORPHOLOGY OF THE AMPHIBIAN ENDOLYMPHATIC ORGAN ${ }^{1}$
}

\author{
W. T. DEMPSTER \\ Department of Anatomy, University of Michigan
}

ONE TEXT FIGURE AND FOUR PLATES (TWENTY-eight FIGURES)

\section{AUTHOR'S ABSTRACT}

An extensive survey of the anatomy of the endolymphatic organ (i.e., endolymphatic sac and duct) has been made on thirty-four species of amphibians.

1. The histological structure is similer throughout the groun; the sac being formed of cubical cells, which grade into the columnar cells of the duct. A part or the whole of the duct is formed of peculiar 'ependyma-like' cells.

duct is formed of peculiar ependyma-like' cells.

2. The organ typically arises from the sacculus, extends to the endolymphatic foramen by which it enters the endocranial cavity. Here the sac-like expansion of the organ lies in the extradural space.

3. Six morphological types of endolymphatic organ may be recognized in the Amphibia. 4. The development of the endolymphatic organ of four of these types has been followed. The structure in each case may be considered to have reached its definitive condition at the time of metamorphosis.

5. The types of sac structure cannot be readily correlated with any habit of the animals possessing them.

6. A discussion is given of the homology, comparative morphology, and function of the organ throughout vertebrates.

\section{CONTENTS}

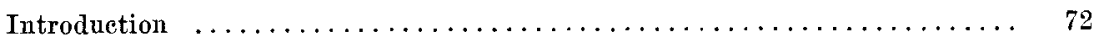

Materials and methods $\ldots \ldots \ldots \ldots \ldots \ldots \ldots \ldots \ldots \ldots \ldots \ldots$

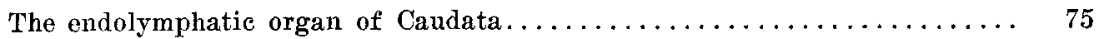

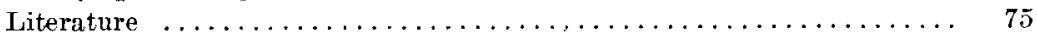

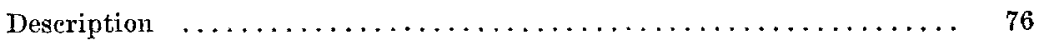

The endolymphatic organ in Salientia................... 91

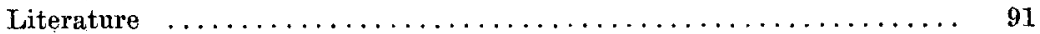

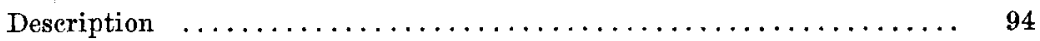

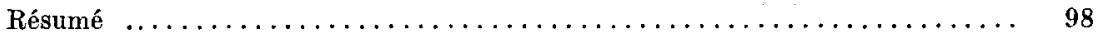

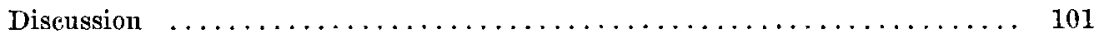

The problem of homology ...................... 101

Comparison of the endolymphatic organ throughout vertebrates..... 104

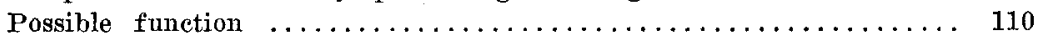

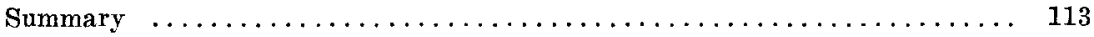

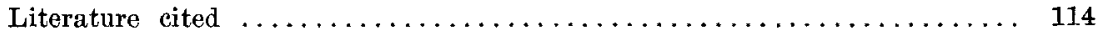

${ }^{1}$ Contribution from the Zoölogical Laboratory of the University of Michigan. 


\section{INTRODUCTION}

Although the amphibian ear has been studied by a number of investigators and its various anatomical units are familiar to morphologists, there are certain phases of the anatomy of the labyrinth that have been somewhat neglected. One structure in particular, the endolymphatic sac, has received relatively little attention in previous investigations, even though the researches of Hasse ('73 a, b) and Coggi ('90 a, b) have indicated that this structure in the Amphibia presents variations of a degree apparently not found in other Tetrapoda.

The expanded condition of the structure, as found in certain amphibians, the calcium content, and immense vascular supply have given rise to speculations as to the significance of the endolymphatic sac in these forms, both from a functional and a phylogenetic point of view. This investigation was undertaken with the hope that a comprehensive morphological study of the endolymphatic sac and duct in a closely related group like the amphibians might reveal evidence regarding the phylogenetic relationships of the structure as found in vertebrates and possibly shed some light on its function.

Aside from a few specific terms whose authority will be mentioned later, the terminology of Retzius ('81 a), generally Anglicized and modified, when possible, to fit the BNA system, has been adopted.

Need has been felt for a term more inclusive than 'endolymphatic sac' and 'endolymphatic duct.' 'Endolymphatic organ' will be applied as a generalized term for the two structures. The 'endolymphatic organ' as used here is not to be construed as the 'endolymphatic organ' of Portmann ('19 et seq.), which to him is a phylogenetic and functional unit consisting of the endolymphatic sac, endolymphatic duct, and sacculus. Since there is no apparent connection between the auditory structures and the true lymphatic system, the terms 'otic' and 'periotic' suggested by Streeter ('18) replace the older terminology ('endolymphatic' and 'perilymphatic') 
where reference is made to the labyrinthine membranes, cavities, and enclosed fluids.

Throughout the course of the present investigation the writer has received the constant assistance and direction of Prof. Peter Okkelberg. Many friends at the University of Michigan, particularly Prof. A. G. Ruthven, Mrs. Helen T. Gaige, Prof. G. C. Huber, Dr. Carl L. Hubbs, and Mr. G. L. Walls, have rendered invaluable aid in the suggestion of technique and the procuring and classifying of material. Most of the urodele material not native to southeastern Michigan was studied during a month spent at Cornell University, where the excellent slides of urodele heads in the collections of Profs. H. D. Reed and B. F. Kingsbury were at the writer's disposal.

\section{MATERIALS AND METHODS}

An extensive survey has been made of the labyrinths of a large number of amphibian forms. In all, thirty-four species, representing twenty-six genera and twelve families, have received attention. The following is a list of the forms studied:

Caudata:

Cryptobranchoidea :

Cryptobranchidae:

Cryptobranchus alleganiensis (Daudin)

Salamandroidea :

Necturidae:

Necturus maculosus (Rafinesque)

Amphiumidae:

Amphiuma means (Garden)

Ambystomidae:

Ambystoma [=Amblystoma maculatum (Shaw)

Ambystoma [ =Amblystoma] jeffersonianum (Green)

Ambystoma [ =Amblystoma] tigrinum (Green)

Rhyacotriton [=Ranodon] olympicus (Gaige)

Salamandridae:

Salamandra atra (Laurentius)

Salamandra maculosus (Laurentius)

Triton cristatus (Laurentius)

Triturus [=Diemyctilus =Notophthalamus] viridescens (Rafinesque)

Triturus torosus (Eschscholtz) 


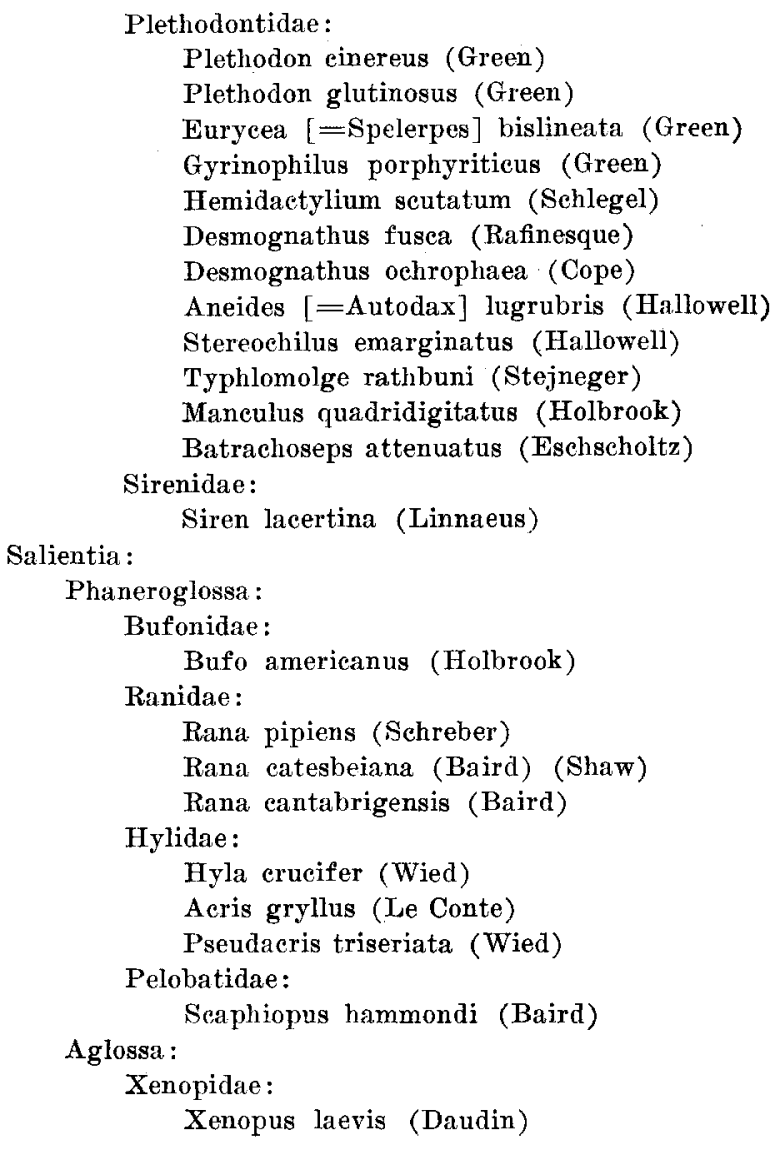

In certain cases as many as thirty preparations involving both embryonic and adult forms have been studied; in others only one specimen was available for examination. The quality and amount of material will be considered in the descriptive section which follows.

In general, specimens were prepared either by intravital fixation or by immersion into the fixing fluid of the dismembered head or head and vertebral column. Zenker's fluid, the Maximow modification of Zenker's fluid, and Champy's fluid were most frequently used for fixing the material. Hydrochloric acid in alcohol was used for decalcification. The material was embedded in celloidin by the Jeffrey hot- 
celloidin process (Plowman, '04; Chamberlain, '15), and serial sections of 15 to $30 \mu$ thickness were cut with a sliding microtome. These were stained in Mayer's haemalum or Heidenhain's iron-hematoxylin and counterstained in eosin, light green, or Congo red.

Born wax-plate reconstructions were made of several labyrinths, using the Huber wax-plate method. Reconstructions were also made by superimposing scale drawings upon one another.

Whenever possible, specimens were studied by gross dissection as well as by microscopic sections, fine knives and dental chisels being used for such dissection.

THE ENDOLYMPHATIC ORGAN OF CAUDATA

\section{Literature}

The endolymphatic organ of urodeles has received only the cursory attention of a few investigators. Calori ('50) observed a white 'thyroid-shaped' mass of calcium within the endocranial cavity of the axolotl lying over the cerebellum and extending from the optic lobes to the medulla, portions expanding ventrally around the roots of the fifth and eighth cranial nerves. Hasse (' $73 \mathrm{a}, \mathrm{b}$ ) demonstrated that this mass represents the contents of the fused endolymphatic sacs of the two sides. He believed, furthermore, that in the axolotl the endolymphatic sacs are not closed, but open into the epicerebral space. ${ }^{2}$

Rex ('93) pointed out that in Salamandra and Triton the endolymphatic sacs are considerably extended, much as in the axolotl. Gage ('93) observed similar expanded diverticulate sacs of Triturus.

\footnotetext{
${ }^{2}$ Various investigators have interpreted differently the meningeal layers in the Amphibia, so that the relations of the endolymphatic sac have been variously described as interdural, intradural, and extradural. The extensive studies of Sterzi ('00-'01, '02) on the comparative anatomy of the meninges, although not entirely satisfactory, are the most complete available. In view of this work, the endolymphatic sac in the Amphibia may be localized in the extradural space (fig. 1).
} 
Kingsbury ('95) showed that the endolymphatic sac of Necturus is different from those of forms previously described, since it forms "a simple sac which rests upon the metaplexus in the immediate neighborhood of the seventh and eighth nerves. Its diverticles are few and very small. ...."

The histological structure of the urodele endolymphatic duct was first described by Okajima ('06, '10, '11 a). In

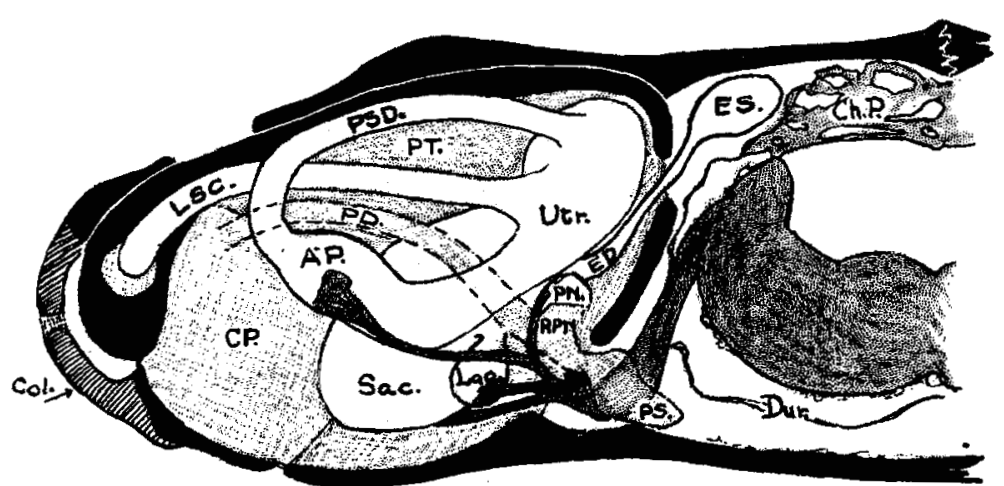

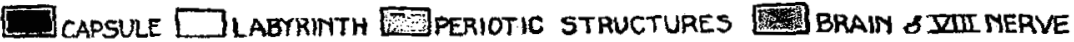

Fig. 1 Diagram of urodele auditory structure. Posterior aspect of left ear of Necturus (from dissection and reconstructions). AP, ampule of posterior canal; $C h P$, choroid plexus; Col, transmitting ossicle; $C P$, cysterna periotica; Dur., dura ; $E D$, endolymphatic duct; $E S$, endolymphatic sac; $L a g$, lagena; $L S C$, lateral semicireular duct; $P D$, periotic duct; $P N$, pars neglecta; $P T$, periotie tissue; $P S D$, posterior semieirenlar duct; $R P N$, recess of pars neglecta; Sac, sacculus; $U t r$, utriculus.

Hynobius, Salamandra, Megalobatrachus, and Onychodactylus, he found a peculiar columnar epithelium which was described as resembling the ependymal lining of the cerebral ventricles. Proebsting ('24) has described a similar structure for the endolymphatic duct in Triton. No one has described the histology of the endolymphatic sac.

\section{Description}

Necturidae. Sections of twenty-three specimens of various stages of Necturus maculosus ranging from embryos of 11 
$\mathrm{mm}$. to young adults were available for study. The youngest preparations show the ear vesicle entirely closed, and consisting of a pyriform cavity lined by an epithelium which varies in thickness from a depth of three nuclei in the basal portion to a simple columnar epithelium of about $40 \mu$ thickness in the apical region. This apical region, the potential endolymphatic duct, is distinctly delimited from the more globular ventral portion of the otic vesicle (fig. 2). Norris ('94) stated that he was unable to decide whether or not the endolymphatic duct in Necturus is formed from the region of closure of the otocyst. At a later stage the internal orifice of the endolymphatic duct is seen to occupy a position mesial to the ear vesicle; the duct itself is reflected dorsally along the medial wall of the vesicle close to the dorsolateral part of the myelencephalon. In an 18-mm. larva, in which the endolymphatic organ is $600 \mu$ long, the endolymphatic sae is apparent as a slight dilatation (fig. 3 ). The cartilage capsule is at this time well differentiated and the semicircular ducts have been formed. Both the endolymphatic duct and sac have elongated in a $40-\mathrm{mm}$. specimen (fig. 5) until the sac now lies over the roof of the fourth ventricle. The epithelium of the organ is columnar. Further growth of the duct in length and a proportionate expansion of the sac constitute the only changes before the attainment of the adult condition.

In dissections of the ear of fully developed adults the endolymphatic sac is seen as a vertically flattened globule lying in the extradural space dorsal to the choroid plexus of the fourth ventricle. A few otolith crystals are usually found in the sac. It is never compactly filled, as in the urodeles possessing expanded sacs. In only one case of a number of ears dissected were there any blood vessels overlying the sac.

Histologically, the endolymphatic organ is formed of a single epithelial layer which is surrounded by a very thin and scarcely differentiated lamina propria (fig. 6). The sac epithelium is a regular cubical epithelium of about $15 \mu$ in thickness. It gradually rises to $20 \mu$ in the upper part of the endolymphatic duct. Within the otocrane, the duct epi- 
thelium becomes rather strikingly modified. It is formed of columnar cells which average $35 \mu$ in height. The nuclei are situated next to the lumen of the duct and the cytoplasm extends outward from the nuclei as pyramidal strands of protoplasm with apices abutting on the thin lamina propria (figs. 6 and 7). The region between the eytoplasmic processes is filled with a clear intercellular substance. That portion of the epithelium lying adjacent to the utriculus remains low, about $15 \mu$ in thickness.

Okajima ('06, '10, '11 a) had observed this epithelium in the endolymphatic organs of several salamanders, and, in view of its superficial resemblance to the ependymal lining of the ventricles of the brain, he referred to this epithelium as ependyma-like, a designation that will be used in this paper.

In Necturus, as in all other Amphibia dealt with here, the wall of the endolymphatic organ is not perforate as Hasse believed it to be. There is no evidence of direct connection between the cavity of the organ and the endocranial spaces.

Cryptobranchidae. A fairly representative series of slides of Cryptobranchus alleganiensis, from stages in which the ear vesicle is not yet closed to young fully metamorphosed adults, was studied. The ear vesicles of 9 - and $10-\mathrm{mm}$. specimens are in the open-placode stage. In a 14-mm. specimen the otocyst is closed, but its dorsolateral aspect lies in contact with the inner layer of the skin, and there is at this time no evidence of a dorsal bulging to form the recessus labyrinthi, but in a 15-mm. specimen this structure is in the form of a well-developed dorsal evagination. At 17-mm. length the recessus labyrinthi has migrated mesially, so that there is a distinct dorsomesial projection $100 \mu$ in length. The epithelium, now approximately $20 \mu$ in thickness, has become regular with a single row of nuclei. In an 18-mm. specimen, in which the horizontal canal has just formed, the endolymphatic organ is over $300 \mu$ in length. A very slight swelling, the beginning of the sac, is apparent at the distal terminus of the organ; its epithelium, however, is indistinguishable from that of the 
duct. Except in its lowermost sixth portion, the duct is separated from the mesial utricular wall. In a $21-\mathrm{mm}$. specimen the duct and sac are $500 \mu$ in length. In a specimen of $27 \mathrm{~mm}$. the sac is more perceptibly swollen and the saccular epithelium may now be distinguished from that of the duct. The saccular lining is cubical and varies in thickness between 15 and $20 \mu$, whereas the columnar epithelium of the duct is about $5 \mu$ thicker. The duct has a length of about $300 \mu$. A 28-mm. specimen presents much the same appearance. The endolymphatic sac has grown so that it lies immediately above the anterolateral portion of the choroid membrane of the fourth ventricle. In a $33-\mathrm{mm}$. specimen the duct and sac remain unchanged; together they are about $800 \mu$ long. The duct shows a slight increase in length in a 34-mm. specimen. The duct and sac in an animal of $39 \mathrm{~mm}$. measure $950 \mu$ in length and retain the same proportions as in younger specimens.

In a young adult of $140 \mathrm{~mm}$. total length, the endolymphatic duct, having a typical origin from the sacculus, extends upward and inward rather free from the utricular wall for $600 \mu$ to the endolymphatic foramen. It passes into the cranial cavity and thence upward another $600 \mu$, where the duct merges more or less imperceptibly with the infundibulum of the endolymphatic sac. The duct has a mean diameter of $50 \mu$. The endolymphatic sac is dilated into a globular vesicle. It does not seem to have a definite vascular supply, but is nested in the dorsolateral portion of the choroid plexus of the fourth ventricle, the dorsal portion of the sac being next to the bony roof of the skull. The origin and development of the endolymphatic organ in Cryptobranchus are quite comparable with those described by Murayama ('28) for Megalobatrachus.

In dissection of adult Cryptobranchi the relations, extent, and content of the endolymphatic sac are almost identical to those of Necturus. The sac lies above the choroid plexus of the fourth ventricle between the dura and the skull vault. It contains a moderate amount of otoconia crystals. 
The endolymphatic sac is formed of regular, low, cubical epithelial cells. That portion of the duct adjacent to it is composed of a columnar epithelium, while the proximal part of the duct, within the otocrane, is formed of the peculiar ependyma-like cells described above for Necturus. Okajima ('06) noted the presence of this epithelium in the endolymphatic duct of Megalobatrachus. The loose periotic and extradural connective tissue lies adjacent to the epithelium of the endolymphatic organ, forming a delicate lamina propria.

Amphiumidae. Six specimens of Amphiuma means were studied. In the youngest, $30 \mathrm{~mm}$. in length, the otic structures are fairly well differentiated. The endolymphatic organ is $400 \mu$ long, the sac forming approximately half of this length. The duct is closely adjacent to the mesial wall of the utriculus and the distinctly ovoid sac overlies the dorsolateral portion of the medulla. The sac has a columnar epithelium, as does also the duct. In a $33-\mathrm{mm}$. specimen the sac has not changed at all, although the duct has elongated to approximately $400 \mu$. At this time the utriculosaccular septum has reached almost its mature extent. In a young adult of unknown length the duct is $600 \mu$ long. It opens distally into the dilated ovoid endolymphatic sac, which is $350 \mu$ at its greatest diameter. In a $165-\mathrm{mm}$. specimen the endolymphatic sac has changed but little. It is still ovoid in shape and the saccular epithelium (not well preserved) is of a low cuboidal type.

Ambystomidae. An adult specimen of Rhyacotriton olympicus shows a somewhat globular sac applied closely to the bony vault of the skull adjacent to the choroid plexus and lying in the extradural space; the plexus is drawn away from the sac and it seems to have no intrinsic blood circulation. The saccular epithelium is of the low, cubical type. Somewhat higher cells line the uppermost, endocranial, portion of the duct, while those of the proximal region have a typical ependyma-like, columnar structure. 
The endolymphatic organ of Ambystoma presents a decided departure from the type of structure found in the salamanders already described. As Hasse ('73 a) has indicated, the endolymphatic sac is markedly dilated so that it surrounds a considerable portion of the brain.

In Ambystoma maculatum the endolymphatic duct arises from the upper mesial wall of the sacculus and extends dorsally along the mesial utricular wall to the endolymphatic foramen. The duct passes through the foramen into the endocranial cavity, where it expands into the endolymphatic sac (figs. 13 and 14). The endolymphatic sac is wide and extends anteriorly and posteriorly. The anterior process extends along the lateral endocranial wall as far forward as the posterior part of the cerebral lobes and fills the space above and anterior to the fifth to eighth cranial nerves. The posterior process extends over the choroid plexus of the fourth ventricle to the midline, where it is fused with the posterior process of the other side. The surface of the endolymphatic sac is lobulate, many small diverticula being evident. Small blood vessels, from the choroid plexus and dural vessels, ramify over the surface of the sac between the diverticula (fig. 15). The whole sac is filled with minute crystals of calcium carbonate.

Histologically, the proximal part of the duct is formed of an ependyma-like epithelium; distally, the epithelium is of the high cuboidal type. The endolymphatic sac is formed of low cubical cells which in places are almost squamous. A thin lamina propria surrounds the epithelium of the endolymphatic organ, being most prominent near the blood vessels of the sac. In none of the developmental or adult stages is there any indication of perforations of the endolymphatic organ such as Hasse ('73 a, b) has described.

In its development the endolymphatic organ is evident as a dorsolateral bulging of the otocyst after the ear vesicle has closed off from the inner layer of surface ectoderm (Norris, '92; Netto, '98). In a specimen measuring $5.5 \mathrm{~mm}$. the endolymphatic-organ anlage is dorsally placed. In a 6-mm. 
specimen it has migrated mesially. In 6.5- and 7-mm. specimens the anlage becomes more distinct. A vertical plica begins to form at $7.5 \mathrm{~mm}$., separating the endolymphatic organ from the otocyst proper. This fold is more prominent in a specimen of $8 \mathrm{~mm}$, and the endolymphatic organ is a distinct dorsomesial diverticulum. In an $8.5-\mathrm{mm}$. specimen (fig. 8) the endolymphatic sac may be recognized as a slight knob on the distal end of the endolymphatic organ. In succeeding stages the duct increases in length and the endolymphatic sac becomes more prominent. It comes to lie over the choroid plexus of the fourth ventricle. The sac in a $17-\mathrm{mm}$. specimen (fig. 9) is markedly expanded, more proportionately than in adults of forms already described. The sac lies above the choroid plexus of the fourth ventricle immediately behind the midbrain. In a $23-\mathrm{mm}$. specimen (fig. 10) the sac has expanded anteriorly so that its forward tip lies along the side of the midbrain. It extends farther forward at $29 \mathrm{~mm}$. (fig. 11) and the sacs of the two sides are in contact. Ependyma-like cells are evident in the duct epithelium. At this time, due apparently to irregular growth of the sac, several small diverticula appear. There are more diverticula in subsequent growth stages. In a 42-mm. specimen (fig. 12) the posterior portions of the endolymphatic sacs have begun to fuse. The structure is much lobulated, and blood vessels are evident ramifying over the surface of the structure. At the time of metamorphosis $(60 \mathrm{~mm}$.) the structure is fully developed.

The relations and extent of the endolymphatic organ are the same in Ambystoma maculatum, A. tigrinum, and A. jeffersonianum.

Salamandridae. The endolymphatic organ of Salamandra atra resembles that of Ambystoma in that the sac is expanded over the dorsolateral aspect of the brain (fig. 16). The endolymphatic duct takes origin from the upper part of the mesial wall of the sacculus just anterior to the pars neglecta, extending dorsomesially at an angle of about $30^{\circ}$ from the horizontal plane to its endocranial dilatation, the endolymphatic 
sac. At first the duct lies along the mesial wall of the utriculus, the epithelia of the two structures being separated by only a few strands of periotic connective tissue. The duct then extends through the endolymphatic foramen to the endocranial cavity. Half to two-thirds of the endolymphatic duct is included within the ear capsule, the remainder being within the cranial cavity. In an adult specimen of $83-\mathrm{mm}$. length the duct has a length of $550 \mu$ and, at its origin from the sacculus, a diameter of $50 \mu$. Distally, the duct lumen has a mean diameter of between 30 and $38 \mu$. There is an infundibuliform expansion of the endolymphatic duct where it joins the sac.

The thin membranous endolymphatic sac lies embedded in the loose meningeal connective tissue external to the dural membrane. The sac extends anteriorly and posteriorly from its point of origin (i.e., the duct) in the midauditory region. The anterior process extends forward along the lateral and upper portions of the mesencephalon to the posterior border of the cerebral hemisphere, occupying most of the space between the brain and the lateral skull wall. At its origin from the duct the sac is wider than deep, but as it extends anteriorly its depth gradually increases. At the region of the fifth nerve root and ganglion the dorsoventral axis of the sac becomes markedly increased until its depth is equivalent to that of the brain itself. A short diverticulum, extending posteriorly from the lower portion of the sac, ends blindly below the fifth ganglion. In the anterior portion the sac slowly diminishes in size until it ends just behind the cerebral hemisphere, usually in two or three small forward-projecting diverticula. That portion of the sac posterior to the duct extends mesially and posteriorly to the region dorsal to the choroid plexus of the fourth ventricle just behind the cerebellum. Here the sac extends to the midline, where it meets its fellow. There is no fusion of the two, although the sacs of the two sides may abut directly on one another. Inconstant posterior processes have been observed in certain specimens (fig. 16). The sac is irregular, presenting certain minor variations in its contour, but is not incised and 
lobulated to the extent that it is in Ambystoma and the anurans. The blood vessels are concentrated on the dorsal aspect and on the mesial side of the sac next to the dural membrane, there being relatively few blood vessels laterally. The blood vessels are continuations of those of the choroid plexus of the fourth ventricle. Dural vessels may also collect tributaries from the sac (Rex, '93).

The histologic structure of the endolymphatic duct is comparable to that found in Ambystoma. The duct arises almost perpendicularly from the saccular epithelium. Its wall is formed of ependyma-like columnar cells ranging in thickness from 20 to $30 \mu$ (fig. 17). As the duct leaves the sacculus the epithelium of the duct gradually changes from the cubic saccular type to the columnar type of the duct proper. Okajima ('10) and Proebsting ('24) have similarly described the structure of the duct in Salamandra and Triton, respectively. At the endolymphatic foramen, or slightly proximal to this structure, the epithelium of the duct becomes slightly thinner and more compact, although the diameter of the duct is the same. The nuclei of this epithelium are more centrally placed, with their axes generally in line with the cell axes. In the endolymphatic sac the nuclei are located centrally in a cubical epithelium of 15 to $18 \mu$ thickness. The cell boundaries are distinct. Where the epithelium is 2 or $3 \mu$ thinner than stated, the cells are correspondingly lengthened. In all probability, such stretching of the epithelium results from the presence of the calcareous substance in the sac. Although in certain cases the epithelia of the sacs of the two sides touch (fig. 19), no fusion has been observed. Surrounding the epithelium of the endolymphatic organ is the loose fibrous tissue of periotic and extradural spaces. It becomes concentrated between the sac and choroid plexus of the fourth ventricle in the region of the meninge primitive (dura), but is elsewhere thin. Pigment cells are occasionally found associated with the connective tissue of blood vessels. The surface of the sac is usually incised or furrowed, so that blood vessels are nearly surrounded by the epithelium (fig. 20). 
In a 12.5-mm. larva the endolymphatic sac is a club-shaped dilatation on the distal end of the endolymphatic duct. The epithelium is cuboidal, with centrally placed nuclei throughout the sac and duct (fig. 21). In a 19-mm. specimen the sac has become dilated and spreads over the region dorsal to the choroid plexus, the shape and relations of the organ at this time being quite comparable to those found in adult Necturus and other aquatic salamanders (fig. 22). The duct at this time shows the first traces of the ependyma-like epithelium. In a 25-mm. specimen the endolymphatic sac has begun to extend anteroposteriorly, diverticula projecting from the body of the sac (fig. 23). The epithelium is now approaching the adult condition. Some idea of the growth and variation of the endolymphatic sac may be obtained by a comparison of its anteroposterior extent in embryos and adults of varying size, as shown in the following table:

\begin{tabular}{|c|c|c|c|}
\hline $\begin{array}{l}\text { LENGTH OF } \\
\text { SPECIMEN (MM.) }\end{array}$ & $\begin{array}{l}\text { LENGTH OF SAO } \\
\text { (MICRA) }\end{array}$ & $\begin{array}{l}\text { AMOUNT ANTERTOR } \\
\text { TO DUCT }\end{array}$ & $\begin{array}{c}\text { AMOUNT POSTERIOR } \\
\text { TO DUCT }\end{array}$ \\
\hline \multicolumn{4}{|l|}{ Larvae: } \\
\hline 12.5 & 120 & & \\
\hline 19 & 440 & 370 & 70 \\
\hline 25 & 690 & 540 & 150 \\
\hline 32 & 1500 & 1190 & 330 \\
\hline Transforming & & & \\
\hline larvae: & & & \\
\hline 42 & 1920 & 1200 & 720 \\
\hline 43 & 2470 & 1840 & 630 \\
\hline \multicolumn{4}{|l|}{ Adult: } \\
\hline 47 & 1930 & 1470 & 460 \\
\hline 60 & 2400 & 2100 & 300 \\
\hline 62 & 1860 & 1160 & 700 \\
\hline 83 & 3750 & 2790 & 960 \\
\hline
\end{tabular}

It is to be noticed that the endolymphatic organ increases as the animal grows. Its earlier development involves a simple expansion of the sac. Differentiation into the structural pattern of the adult occurs rather late in development, just before and during metamorphosis. In adult development there is a further expansion in relation to the increasing size of the brain and endocranial cavity. 
The one adult specimen of Salamandra maculosus that was studied exhibits an endolymphatic sac and duct that are indis. tinguishable both histologically and in general relationship from those of Salamandra atra. This is likewise true for one adult specimen of Triton cristatus studied.

Adults specimens of Triturus viridescens and Triturus torosus exhibit endolymphatic organs that are identical in size, structure, contents, and relations with those of Salamandra and Triton. Although I have not seen a departure from the salamandrid type, Mrs. Gage ('93) noted that "in one specimen [of Triturus viridescens] the sacs unite over the meson as they are said to in the frog."

Plethodontidae. The endolymphatic sac in Gyrinophilus porphyriticus is of the bulbar or spherical type. In an adult specimen of $140 \mathrm{~mm}$. the sac has an approximate diameter of $500 \mu$. It is, however, somewhat flattened where it closely approximates the bony roof of the cranial cavity. The duct, extending from the sacculus to the sac, is slightly more than $500 \mu$ in length. The saccular epithelium is cuboidal; that of the duct is columnar distally and ependyma-like in its proximal portion. The endolymphatic sac and that portion of the duct within the cranial cavity lie upon the membranes of the choroid plexus of the fourth ventricle. There is no indication of a specific vascular supply. Larvae $63 \mathrm{~mm}$. and $95 \mathrm{~mm}$. in length show no perceptible differences in the structure of the organ from that of the adult.

An adult specimen of Typhlotriton spelaeus that was studied presents the small spherical type of sac, not over $400 \mu$ in diameter. It lies above the choroid plexus of the fourth ventricle in the extradural space, extending forward from the duct. The epithelium of the sac is typically cuboidal, while that of the duct appears very thin and is poorly preserved. An $82-\mathrm{mm}$. larva in very poor state of preservation gives auxiliary data, the sac being of the small type.

Stereochilus emarginatus has the small bulbar type of sac, with a maximum diameter of $300 \mu$ in an adult specimen. The endolymphatic duct presents a cubical epithelium in its endo- 
cranial portion, and the otocranial portion is formed of tall ependyma-like cells, although this is not particularly distinet in the preparation studied. The periotic and meningeal connective tissues form a very thin layer around the duct and sac. In a larval specimen of unknown length the sac is of the same size as that of the mature specimen, and the duct has the same structure as that of the adult.

Various stages of Spelerpes bislineatus were studied. In the youngest of these the horizontal canal is not yet completely differentiated and the endolymphatic duct and sac originate as an evagination from the mesial side of the ear vesicle. The epithelium is cuboidal. In a $15-\mathrm{mm}$. larva the sac is small and globular, and has a diameter of $130 \mu$. It is lodged in the angle between the posterior part of the mesencephalon and the roof of the fourth ventricle. The epithelium of the sac is of a low columnar type. In an animal of $20-\mathrm{mm}$. length the sac has a diameter of $120 \mu$. The sac epithelium is cubical, while that of the duct is columnar with nuclei adjacent to the lumen. A 25-mm. larva and one of $31 \mathrm{~mm}$. have sacs $165 \mu$ in diameter. In $37-\mathrm{mm}$. and 55-mm. specimens the duct epithelium is ependyma-like.

In Desmognathus fusca the spherical endolymphatic sac is above the choroid plexus of the fourth ventricle, lateral and posterior to the mesencephalon. The epithelium of the sac is cubical and the ependyma-like columnar cells lining the endolymphatic duct in its lower third thin out distally and become cubical. The diameter of the sac in a young adult is approximately $180 \mu$.

Two specimens of Desmognathus ochrophaea show slightly larger sacs, namely, $270 \mu$ in diameter in a transforming larva of $16.5 \mathrm{~mm}$. and $285 \mu$ in one of $15 \mathrm{~mm}$. The sac appears somewhat expanded. Its epithelium is very thin, almost squamous, while the duct is lined by ependyma-like columnar cells which become low and regular distally.

Of the two sectioned adult specimens of Typhlomolge rathbuni which were available, one appeared suitable for description. The endolymphatic duct has its origin from the upper- 
most part of the sacculus immediately anterior to the pars neglecta, and extends dorsomedially for a distance of $400 \mu$, perforating the medial wall of the otocrane and opening funnelwise into the endolymphatic sac. The sac extends 500 to $600 \mu$ over the roof of the fourth ventricle toward the midline, and 600 to $700 \mu$ posteriorly from the duct opening. The bulbar sac has a very low cubical epithelium; that of the duct, though not distinct in the preparations studied, seems to be of a rather low columnar type. This appearance is probably due to autolysis of the external vacuolate parts of the cells.

The one adult specimen of Manculus quadridigitatus examined has a relatively small endolymphatic sac, approximately $200 \mu$ in diameter. The typical saccular epithelium is in contact with the bony vault of the cranial cavity immediately above the dura and choroid plexus of the fourth ventricle. The endolymphatic duct appears swollen; the lining cells seem to be of a simple squamous type, due probably to autolysis of their peripheral vacuolate regions.

The endolymphatic organ of Hemidactylium scutatum, like that of the foregoing plethodonts, is of the small vesicular type.

In Plethodon cinereus the structure of the endolymphatic organ is markedly different from that in the plethodonts already described, approaching that of the Salamandridae, from which, however, it presents certain distinct differences. In a 10-mm. specimen of Plethodon cinereus the epithelium of the endolymphatic duct is columnar. The duct extends dorsomesially from the upper mesial portion of the sacculus into the cranial cavity, expanding into the relatively large endolymphatic sac which is prolonged anteriorly along the side of the mesencephalon and mesially above the choroid plexus of the fourth ventricle. The sac has an anteroposterior extent of $380 \mu$. In a $13-\mathrm{mm}$. specimen the structure and relations are similar to those of the younger specimens. The structure of the endolymphatic sac in a $15.5-\mathrm{mm}$. specimen approaches that found in the adult. A process of the sac 
extends mesially over the anterior portion of the fourth ventricle, immediately posterior to the mesencephalon. Lateral to the mesencephalon the sac is prolonged forward nearly to the diencephalic region. In the region of the fourth ventricle the epithelium is cuboidal, but anteriorly it thins out to the pavement type. The sac appears moderately vascular. Distally, the duct epithelium is low; it is slightly higher and is ependyma-like within the ear cavity. In a 17-mm. specimen the sac is distended; it extends $470 \mu$ anteriorly and $140 \mu$ posteriorly from the junction of the endolymphatic duct. The posterior portion is formed of low cubical cells which are quite thin on the lower aspect of the sac; the anterior process of the sac is lined by a relatively thick pavement epithelium. The endolymphatic-duct epithelium is typical. An 18-mm. specimen is similar, the sac extending $590 \mu$ anterior to the duct and $90 \mu$ caudad. In an adult of $24 \mathrm{~mm}$. the endolymphatic sac measures $270 \mu$ posterior to the duct orifice and $470 \mu$ anteriorly. The posterior portion is flattened and extends over the roof of the fourth ventricle to the midline. Anteriorly, the sac reaches the posterior part of the cerebral hemisphere lateral to the mesencephalon. A constricted region immediately anterior to the endolymphatic duct connects the anterior and posterior prolongations of the sac. The squamous epithelium becomes cuboidal in the dorsal posterior portion of the sac. The epithelium of the proximal part of the duct is of a high ependyma-like columnar type, with nuclei typically situated next to the lumen. Where the duct is adjacent to the utricular wall the lining cells are low. Distally, the epithelium of the duct approaches the type found in the sac.

The endolymphatic organ of a $20-\mathrm{mm}$. young adult Plethodon glutinosus is similar to that of $\mathrm{P}$. cinereus. The constriction of the sac anterior to the duct is very distinct. The sac extends $930 \mu$ anteroposteriorly, $670 \mu$ of this length being anterior to the duct (fig. 25).

A 48-mm. adult of Aneides lugrubris has a large expanded sac much like that of Salamandra or Plethodon, extending 
$1900 \mu$ anterior to the duct and $720 \mu$ posteriorly. The exact configuration of the sac and the histologic details are obscured by cytolytic changes, but the epithelium appears similar to that of other salamanders.

In an 83-mm. adult Batrachoseps attenuatus, the endolymphatic sac is large, resembling that found in Salamandra. It has an anteroposterior diameter of $1270 \mu$, extending from the ninth nerve to the region above the trigeminal ganglion. The widest part is immediately posterior and lateral to the mesencephalon. The sac narrows laterally to the mesencephalon, as in Plethodon, and is here joined by the endolymphatic duct. Anteriorly, there is an expansion, the greatest diameter being vertical. The tip of the sac lies at the posterior end of the cerebral hemisphere approximately at the same transverse level as the most anterior part of the superior duct. The posterior portion is in contact ventrally with the choroid plexus of the fourth ventricle, and the whole structure lies in the extradural space. Anteriorly, the sac seems to be fairly well supplied with specific blood vessels. The lining of sac and duct is not well preserved, but appears squamous, except in certain portions of the sac, where the cells are cubical.

Sirenidae. Sections of two young adult specimens of Siren lacertina, one of $133-\mathrm{mm}$. length and the other of unknown length, have been studied. The sections of both of these specimens are not ideal; the otocrane membranes are much collapsed and the proximal part of the endolymphatic duct cannot be distinguished. The endolymphatic sac, however, is of the small bulbar type and is close to the roof of the skull cavity above the fourth ventricle. The epithelium is of a low cubical type. The sac extends anteroposteriorly nearly $400 \mu$.

Hynobiidae. Okajima ('10, '11 a) has noted that the endolymphatic duct in Hynobius and Onychodactylus is formed of an ependyma-like epithelium. He does not describe the sac. A specimen of Hynobius nebulosus examined by the writer showed the duct formed of ependyma-like cells and the small globose sac formed of cubical cells. 
THE ENDOLYMPHATIC ORGAN OF SALIENTIA

\section{Literature}

The frog (Rana) has an enormously expanded endolymphatic sac, which extends through the spinal canal, small diverticula extending out through the intervertebral foramina forming globose chalky masses around the spinal ganglia. These sacs and their white, semifluid contents, visible in abdominal dissection of the frog, were observed as long ago as 1681 by Blasius, but were not understood to have any relation to the ear. Carus (1827) first drew attention to the similarity between these bodies and the sacculus of the ear, saying:

.... the little sacculus .[of the ear] filled with chalky matter is almost exactly similar to the remarkable chalky milky bodies at the intervertebral foramina for the spinal nerves: so that these remarkable bodies so mysterious to many naturalists are merely repetitions of the secretion within the internal ear. As one vertebra frequently represents the form, and one nerve the course of another, why may we not suppose that a secretion between two eranial vertebrae may reproduce itself between two spinal vertebrae?

Lenhossek ('86) described the histological structure of these extravertebral units. He pointed out that the calcareous sacs cap the ganglia and posterior nerve roots, a common capsule surrounding both. He regarded the calcareous bodies as consisting of convoluted tubules of three or four layers and having a regular cubical epithelium (14 to $15 \mu$ ). The organs were quite vascular and Lenhossek was led to believe that they were ductless glands which secreted calcium salts. Hasse ('73 b), studying the endolymphatic duct of the frog, found it extending into the cranial cavity and combining with a thin-walled endolymphatic sac filled with numerous crystals of calcium carbonate similar to those of the labyrinth. He was of the opinion that this sac extended as a complete ring around the medulla.

Coggi ('90 a, b) was the first to recognize the extent of the endolymphatic sac in the frog. In adults and larvae of Rana esculenta and Rana agilis he found that the endolymphatic 
ducts of the two sides unite with the endolymphatic sac which extends around the brain as indicated by Hasse. There is a posterior continuation of this sac which occupies the middorsal wall of the vertebral canal, posterior to the spinal cord, and extends to the coccyx. It sends transverse appendages into the upper part of the intervertebral foramina to the region of the spinal ganglia. The structures split dichotomously and cover the ganglia. The structure becomes rather irregular in its appearance, there being numerous little pouches or prominences which are superficially apparent. The sac is formed of a single layer of epithelium covered by a delicate framework of lamellated connective tissue. There is a very rich blood supply, fine capillaries ramifying among the prominences of the sac. Coggi believed that the organ was covered by the pia, but the studies of Sterzi on the meninges discredit this relation.

Gaupp ('97), dealing with Rana esculenta and Rana temporaria, described the endolymphatic sac, giving attention to the endocranial portion of the sac and suggesting the use of convenient descriptive terms. That portion of the endolymphatic sac anterior to the endolymphatic foramen is the pars cranialis. An ascending process, the processus ascendens anterior, extends over the midbrain, fusing in the midline with its fellow and with the paraphysis. A ventral process, the processus descendens, extends downward between the trigeminal ganglion and the oculomotor foramen to the ventral part of the brain, where it unites with the anterior lobe of the hypophysis. The pars posterior, continuous with the pars cranialis, extends posterior to the endolymphatic foramen. It sends a processus ascendens posterior over the forepart of the choroid plexus of the fourth ventricle, forming a second band across the brain, and a processus spinalis posteriorly along the lateral boundary of the choroid plexus. At the hind portion of the choroid plexus the processus spinalis of the two sides meet and unite, forming the pars spinalis, which extends to the seventh vertebra, where the halves again separate. From the pars spinalis, diverticula 
(processus transversi) extend through each intervertebral foramen and over the spinal ganglia, forming swollen sacculi.

Gaupp further pointed out that the endolymphatic sac receives a copious vascular supply from the vena spinalis dorsalis, a tributary of the internal jugular vein, which lies in the dura along the ventral wall of the spinal part of the endolymphatic sac.

Although Portmann ('21 c) has more recently described the endolymphatic sac in the frog, his text and figure indicate that he has confused periotic structures with the endolymphatic organ.

Whiteside ('22) reviewed the development of the endolymphatic sac in Rana temporaria.

In a larva of $4 \mathrm{~mm}$. length, whose auditory organ is in an advanced state of development, the saceus endolymphaticus is present only as a slight expansion of the distal end of the ductus. . . . The further development of the saccus proceeds very slowly. First an increase in length takes place in a cranio-caudal direction, until the saccus reaches from the hemispheres into the region of the seventh vertebra, the saccus of one side remaining separated, however, from that of the opposite side.

Later the sacs of the two sides fuse in the midline, the anterior ascending process first, then the spinal portion, and finally the posterior ascending process. The periganglionic calcareous sacs-

attain their definitive form at the end of the metamorphosis. At the time of its first appearance, the saceus endolymphaticus is an undivided sac lined by a single layer of epithelium. It soon becomes partitioned into two tubuli which later subdivide into smaller ones. During the course of development, the saccus is divided more and more into small tubuli until it finally has the appearance of a glandular structure. The histological structure of the cells lining the saccus endolymphaticus remains practically the same during the whole period of development. The cells are first cylindrical in shape, later they are cuboidal. Blood vessels are present at first only in small numbers, but later become very numerous. The calcareous contents of the saccus exist almost from the very beginning. 
The earlier stages of the embryology of the duct and sac are treated by Michl ('25) and Fineman ('15). Their descriptions are in essential agreement with those of Whiteside.

Anurans other than Rana have been studied. Coggi pointed out that in Hyla arborea the venous sinus is unpaired and not bifurcate. In Bufo, however, the venous structures are described as four sini derived from the choroid plexus of the fourth ventricle The sac itself is described as partly overlying the choroid plexus. The segmental diverticula of the sac are not obvious. Coggi further pointed out that the extent of the endolymphatic sac is different in Discoglossus pictus and Bombinator igneus, but did not describe the condition found.

Wenig ('13) found the endolymphatic sacs of Pelobates larvae to be paired elongated sacs extending along the lateral boundary of the choroid plexus--a condition comparable to certain of the stages of Rana described by Whiteside. He also noted the presence of ependyma-like cells in the endolymphatic duct.

\section{Description}

Ranidae. Specimens of Rana pipiens were examined by gross dissection and by means of serial sections. In the gross relations of the endolymphatic organ this species differs little from that described by Gaupp ('97) (fig. 26). The endolymphatic duct arises as a cylindrical tube from the sacculus slightly anterior to the pars neglecta and extends dorsomesially to the endolymphatic foramen, mesial to the midpart of the utriculus. As it passes through this foramen the duct opens into the expanded endolymphatic sac, which possesses in the terminology of Gaupp a pars anterior and a pars posterior. The whole of the endocranial part of the endolymphatic organ lies within the extradural space. The spinal portion is partly within the extradural space and partly outside of the vertebral canal. The processus ascendens anterior extends dorsally from the pars anterior to meet its fellow in the region above the paraphysis. The processus descendens 
extends downward and terminates on the lateral boundary of the anterior hypophysis. The posterior ascending process extends dorsally toward the midline, but does not reach it. There are thus not two dorsal bands, as Gaupp described, but only one. The pars spinalis and the spinal process are as described by Gaupp, with the exception that the posterior terminus of the sac becomes constricted gradually to a point lying in the urostyle cavity. The periganglionic diverticula (fig. 27) are well developed and bound the ganglia ventrally and anteriorly. The sac is folded into many ridges, or villi, between which the blood vessels run. The blood supply is derived from the dorsal dural vein and, apparently, also from small vessels from the paraphysis. The epithelium of the endolymphatic sac is typically cubical. It becomes thinner in places, approaching a thick pavement epithelium, but this is probably due to distention of the sac by its calcium content. The extradural connective tissue closely invests the sac, being particularly prominent in the region between the villosities of the sac and around the blood vessels. The endolymphatic duct throughout its whole course is made up of the ependymalike type of cell so characteristic of the lower portion of the endolymphatic duct of salamanders. The whole endolymphatic sac is filled with small crystals of aragonite.

The endolymphatic organ of Rana catesbeiana, in gross dissection, appears to be of the same type, as to extent, relations, content, and vascular supply, as described for Rana pipiens.

Xenopidae. One specimen of Xenopus mulleri which was examined has an endolymphatic sac of the same structure and extent as that of Rana. The anterior ascending processes of the sac, however, are reduced and do not meet above the brain. Its epithelium is of the thickened pavement type and, although the epithelium of the duct does not show ependymalike cells, their presence may be obscured by poor fixation (i.e., museum preservation). The structure is very vascular, its blood supply extensively involving the dural vessels.

Specimens of Xenopus laevis on dissection showed crystalline accumulations in the endolymphatic sac. 
Bufonidae. In the adult Bufo americana the endolymphatic organ has a markedly enlarged endolymphatic sac somewhat similar in its relations to that of Rana (figs. 28 and 29). In several preparations the endolymphatic duct appears to have a cubical epithelium, its ventralmost portion showing the vacuolate structure found in Rana, however. The duct opens at the endolymphatic foramen into the enlarged endolymphatic sac. Its epithelium is of a low cubical type. This sac presents anterior and posterior specializations. The descending process, terminating on the lateral boundary of the hypophysis, is similar to that of Rana. The anterior ascending process extends to the midline above the paraphysis, where it joins that from the other side. From this region a process of the sac, which I shall call the intercerebral portion (pars intercerebralis), extends forward, above and between the cerebral lobes, to the region dorsal to the olfactory nerves. Here there is a somewhat expanded terminal dilatation of the process. The posterior ascending process extends toward the midline, posterior to the cerebellum, but does not meet the process from the other side. Posteriorly, as in the frog, there is a spinal portion of the sac which extends into the proximal portion of the urostyle above the terminal filament of the nerve cord. Paired lateral processes extend through the intervertebral foramina for a short distance enveloping the nerve roots, but not the spinal ganglia. The wall of the endolymphatic sac is composed of projecting diverticula or villosities between which are found the blood vessels. The blood supply consists largely of a dorsal dural vein arising from tributaries in the spinal portion of the sac extending forward in the midline along the ventral border of the sac to the posterior portion of the choroid plexus of the fourth ventricle. Here it separates into right and left portions which join the jugular veins. Anteriorly, a large dural vein arising from the olfactory region divides into usually unequal right and left portions which extend backward, joining the posterior dorsal dural veins. 
In the developmental stages which have been studied, the embryological sequence is similar to that described by Whiteside ('22) for the frog. The duct first makes its appearance as a dorsal diverticulum from the otocyst in a toad of about 4-mm. total length. In a specimen of about $7 \mathrm{~mm}$. the endolymphatic organ has migrated to the dorsomesial portion of the ear vesicle. The structure is more pronounced in a 9-mm. specimen. Slight anterior and posterior expansions are evident in the sacs of a $10-\mathrm{mm}$. specimen. This expansion progresses in specimens from 10 - to $16-\mathrm{mm}$. length, when the whole structure has the same anteroposterior extent as the inner ear itself. The sac of each side is pointed anteriorly and posteriorly and is widest in its midregion. In a $17-\mathrm{mm}$. specimen the posterior portion of the sac extends along the lateral edge of the choroid plexus beyond its posterior terminus. Anteriorly, the process has extended as far forward as the hypophysis and there is no evidence of fusion of the sacs of the two sides. In a specimen of maximum larval length ( 20 to $21 \mathrm{~mm}$.) the anterior ascending processes of the endolymphatic sacs of the two sides have fused, and the spinal portions have come together posterior to the choroid plexus. The spinal portion extends to the region of the urostyle. The intercerebral diverticulum has begun to form at this time. Few blood vessels are evident, although the sac at this time has begun to develop an irregular surface. During metamorphosis the posterior ascending process appears, the lateral processes of the spinal portions of the sac extend more intimately around the nerve roots, and the structure of the sac approaches the adult condition with the typical adult blood supply. The epithelium throughout the embryological period has remained of a low cubical type.

Hylidae. In Hyla versicolor the endolymphatic organ has the same relations as that of Bufo. The endolymphatic duct is formed of a regular cubical epithelium; its lowermost portion possesses the ependyma-like cells described above. At the endolymphatic foramen the duct opens into the sac, which possesses the same processes, having the same extent as Bufo. The sac epithelium is cubical. 
The relations are similar in Pseudacris triseriata and Acris gryllus.

Pelobatidae. A specimen of Scaphiopus hammondi at a stage late in metamorphosis, when the tail is almost resorbed, has an endolymphatic organ which in extent and structure is identical to that of the Bufonidae and Hylidae.

\section{RÉSUMÉ}

The endolymphatic organ of amphibians presents a high degree of constancy in certain of its features. The epithelium of the sac is typically cubical, and the endolymphatic duct is wholly or in part formed of an ependyma-like epithelium. In contrast to the condition of certain vertebrates, no free cellular inclusions are found in the amphibian endolymphatic organ. The relations of the endolymphatic organ to the auditory organ and to the meninges are the same throughout the group.

On the other hand, certain differences, chiefly relative to the extent of the endolymphatic sac, are apparent. In the preceding descriptions a contrast was evident between a small club-shaped non-vascular endolymphatic organ found in some forms and the enlarged vascular and calcium-filled organ of other forms. This latter type presents several variations in different groups, so that on the basis of morphological peculiarities six distinct types may be recognized.

Type I consists of an organ having a small globose or vesicular expansion terminating the endolymphatic duct. Blood vessels are rarely found associated with either duct or sac. Calcium-carbonate crystals, if found at all in the sac, are few in number. This type is found in the following forms: Necturus maculosus, Amphiuma means, Cryptobranchus alleganiensis, Siren lacertina, Rhyacotriton olympicus, Hemidactylium scutatum, Gyrinophilus porphyriticus, Desmognathus fusca, D. ochrophaea, Stereochilus emarginatus, Typhlotriton spelaeus, Maneulus quadridigitatus, Typhlomolge rathbuni, and Hynobius nebulosus. 
In type II the sac is expanded along the side of the brain in a craniocaudal direction. The anterior tip of the sac is just posterior to the cerebral hemisphere and the posterior portion overlies the choroid plexus of the fourth ventricle. The sac itself is rather wide. Its surface is irregular and somewhat folded. The sacs of the two sides do not fuse. The structure is quite vascular, and small vessels and capillaries from the anterior cerebral vessels and the choroid plexus ramify over its surface. Normally the organ is filled with minute aragonite crystals. Type II is characteristic of the Salamandridae (Salamandra atra, S. maculosa, Triton cristatus, Triturus viridescens, $\mathrm{T}$. torosus).

In type III the sac has the same general relations and extent as type II. It has, however, a constricted region anterior to the endolymphatic duct which separates the anterior and posterior expanded parts. Its epithelium is a very low cubical type which becomes higher in the constricted region. As in the previous type, it contains calcium-carbonate crystals. Plethodon cinereus, $\mathrm{P}$. glutinosus (and possibly Aneides lugrubris and Batrachoseps attenuatus) are examples possessing this type.

Type IV has a large endocranial sac formed from the fused endolymphatic sacs of the two sides, and, like the former types, it lies in the extradural space. The sac extends over the medulla and posterior portion of the mesencephalon and extends anteriorly on the side of the brain as far forward as the cerebral hemisphere. The surface of the sac is deeply incised by irregular crypts in which lie the many blood vessels supplying the organ. Blood vessels are chiefly derived from the choroid plexus. The sac is filled with chalk crystals. This type is found in the following forms: Ambystoma maculatum, A. tigrinum, and A. jeffersonianum of the Ambystomidae.

Types V and VI are found in the Anura. In the former the endolymphatic sacs are large and lie in the extradural space of both the endocranial and vertebral cavities. The portion anterior to the endolymphatic duct consists of a dorsal 
process which meets its fellow above the 'tweenbrain and a ventral diverticulum which fuses with the hypophysis. Two processes extend posterior from the region of the duct along the edge of the choroid plexus of the fourth ventricle and fuse at its posterior margin. This median body, so formed, extends posteriorly over the spinal cord to the urostyle. Paired segmental processes extend through the intervertebral foramina and invest the spinal ganglia. The sac and duct are filled with aragonite crystals. The structure is very vascular, the main blood supply coming from the dorsal dural vein. Type $V$ characterizes the Ranidae (Rana pipiens, $R$. catesbeiana, R. agilis, R. temporaria, R. esculenta). It is also found somewhat modified in Xenopus.

Type VI is similar to the former. It has, however, an anterior prolongation of the endolymphatic sac dorsal to and between the cerebral lobes. Associated with the anterior prolongation of the sac are the large cephalic dural veins. Crystals of calcium carbonate form the contents. Type VI is demonstrated in the Bufonidae (Bufo americanus), the Hylidae (Hyla crucifer, Acris gryllus, Pseudacris triseriata), and the Pelobatidae (Scaphiopus hammondi).

The ear in Amphibia presents differences which are of phylogenetic importance. Among these are the structures of the sound-transmitting ossicles, auditory capsule, acoustic nerve, and sense organs. The endolymphatic organ likewise presents differences of some taxonomic importance. Although it is similar in the Necturidae, Cryptobranchidae, Amphiumidae, Hynobiidae, and Sirenidae, it is essentially different in the Salamandridae and the Ambystomidae. Two distinct types of endolymphatic organ are found in the Ambystomidae. The division of the family into two groups of genera, the first containing the species of Ambystoma and the second consisting of Rhyacotriton and Dicamptodon (Noble, '27) may be confirmed on the basis of auditory structure. In the Plethodontidae the endolymphatic organ indicates a division of the genera into two groups. Plethodon cinereus, P. glutinosus, Aneides lugrubris, and Batrachoseps attenuatus have 
expanded endolymphatic sacs, while the other genera dealt with have club-like endolymphatic organs. Noble ('27) recognized two groups of plethodonts, those more or less terrestrial forms, arising from Plethodon (i.e., Hemidactylium, Batrachoseps, Ensatina, and Aneides), and those of the mountain brook habitat (with Gyrinophilus as the primitive example). Noble's two groups correspond with those of the writer except for one point. Hemidactylium has a club-like endolymphatic organ, and because of this difference it is hardly likely that this form "evolved from Plethodon merely by the loss of a fifth toe."

\section{DISCUSSION}

\section{The problem of homology}

Since the early work of Balfour ('80), who believed that the region of closure of the ear vesicle in higher forms was homologous with that tube which in the Selachia connects the labyrinth with the exterior, a number of investigators have studied the early embryology of the ear in an attempt to determine whether the so-called endolymphatic organ was homologous in various vertebrates. Attention has been centered primarily upon the question of the equivalence of the endolymphatic organ-forming tissues and the last point of closure of the otocyst. Several workers have considered two other points in the development of the endolymphatic organ, as may be seen in the accompanying tabular summary of literature.

It is evident that the literature on the subject of the homology of the endolymphatic organ reveals many conflicting views, so that almost any interpretation is possible. A fallacy is apparent in most of the studies on the homology of this organ in that only the incipient stages in the development of the structures have received attention. If a difference is apparent in the early stages of the endolymphatic organ of two forms, the structures are regarded as not homologous. In the opinion of the writer such discussion would appear to be quite futile. 
Tabular summary of the literature on the homology of the endolymphatic organ

\begin{tabular}{|c|c|c|c|c|}
\hline & $\begin{array}{l}\text { ENDOLPMPHATIC } \\
\text { ORGAN DERIVED } \\
\text { FROM REGION OF } \\
\text { CLOOURE OF } \\
\text { EAR VESICLE }\end{array}$ & $\begin{array}{l}\text { ENDOLYM- } \\
\text { PHATIC ORGAN } \\
\text { FORMED DOR- } \\
\text { SALLY TO THE } \\
\text { REGION OF } \\
\text { CLOSURE OF } \\
\text { EAR VESIOLY }\end{array}$ & $\begin{array}{c}\text { DUCT PRO- } \\
\text { DUCED BY FOR } \\
\text { MATION OY A } \\
\text { PLICA } \\
\text { VERTICALIS }\end{array}$ & $\begin{array}{l}\text { ENDOLYMPHATIC } \\
\text { ORGAN } \\
\text { PRODUCED } \\
\text { BY LATE } \\
\text { EVAGINATION }\end{array}$ \\
\hline $\begin{array}{l}\text { Oyclostomes } \\
\text { Hagfish: } \\
\text { Kupffer ('00) } \\
\text { Lamprey: } \\
\text { Krause ('06 a) }\end{array}$ & * & * & & \\
\hline $\begin{array}{l}\text { Selachia: } \\
\text { Fishes } \\
\text { Balfour ('90) } \\
\text { Hellman ('98) } \\
\text { Mitrophanow ('90,'93) } \\
\text { Krause ('06 b) } \\
\text { Wenig ('12) } \\
\text { Fineman ('15) } \\
\text { Ranzio ('24) } \\
\text { Dipnoi: ('19) } \\
\text { Kerr ('19) } \\
\text { Ganoid: } \\
\text { Fineman ('15) } \\
\text { Teleost: } \\
\text { Oryzias: } \\
\text { Murayama ('27) } \\
\text { Carp: } \\
\text { Sidoriak ('98) } \\
\text { Salmo: } \\
\text { v. Noorden ('85) } \\
\text { Krause ('06) b) } \\
\text { Wenig ('12) } \\
\text { Fineman ('15) } \\
\end{array}$ & $\begin{array}{c}\text { Duct opening } \\
\text { persists } \\
* \\
* \\
* \\
\star \\
* \\
* \\
\text { No endolym- } \\
\text { phatic duct }\end{array}$ & * & . & $\begin{array}{c} \\
* \text { (From ventral } \\
\text { side of otocyst) } \\
* ? \\
*\end{array}$ \\
\hline $\begin{array}{l}\text { Urodele: Amphibia } \\
\text { Norris ('92,'01) } \\
\text { Netto ('98)' } \\
\text { Krause ('01, '06 b) } \\
\text { Okajima ('11) } \\
\text { Murayama ('27) } \\
\text { Anura: } \\
\text { Poli ('97) } \\
\text { Wenig ('12) } \\
\text { Fineman ('15) } \\
\text { Ranzio ('24) } \\
\text { Michl ('25) }\end{array}$ & * & $\begin{array}{l}* \\
* \\
* \\
*\end{array}$ & * & \\
\hline $\begin{array}{l}\text { Leptiles } \\
\text { Lizard: } \\
\text { Hoffman ('90 b) } \\
\text { Peter ('O1) } \\
\text { Fleissig ('03) } \\
\text { Fineman ('15) } \\
\text { Turtle: } \\
\text { Perovic ('14) } \\
\text { Keibel ('15) } \\
\text { Hochstetter ('16) }\end{array}$ & $\begin{array}{l}* \\
* \\
* \\
*\end{array}$ & * & * & \\
\hline $\begin{array}{l}\text { Birds } \\
\text { Poli ('97) } \\
\text { Keibel ('99) } \\
\text { Rothig and Brugsch ('02) } \\
\text { Krause ('06 b) } \\
\text { Fineman ('15) } \\
\text { Ranzio ('24) }\end{array}$ & $\begin{array}{l}* \\
* \\
* \\
*\end{array}$ & * & & \\
\hline \begin{tabular}{l}
\multicolumn{1}{c}{ Mammals } \\
Alexander ('00,'01 a) \\
Krause ('06 b) \\
Streeter ('07) \\
Perovic and Aust ('15) \\
Fineman ('15) \\
Ranzio ('24)
\end{tabular} & $\begin{array}{l}* \\
* \\
* \\
*\end{array}$ & $\begin{array}{l}\text { * } \\
\text { * }\end{array}$ & & \\
\hline
\end{tabular}


The endolymphatic organ is the resultant of certain morphogenic processes acting upon the undifferentiated tissue of the auditory placode. Such organogenic influences, intrinsic and extrinsic, must be conceived of as amenable to variation, for it is through such variation that the differences in the fully developed organs in the various animal groups are brought about. These ontogenetic influences may not only differ in intensity, but in their sequence in various animals.

In Ambystoma, for instance, whose auditory structures have been examined embryologically by several investigators (Norris, '92; Netto, '98; Krause, '01, '06 b; Landacre, '26; '27; Kaan, '26, and the present writer), the stages in the development of the endolymphatic organ may be enumerated as follows: 1) Separation of the otocyst from the neural layer of the skin by a constriction of the open lips of the evaginated auditory placode. 2) The formation of a dorsal evagination, the recessus labyrinthi, at the point of closure, or above. 3) A laterodorsomesial rotation of the auditory vesicle (shown experimentally by Miss Kaan, the dorsal half of the otocyst forming the endolymphatic organ and sacculus, the ventral half the pars superior). 4) Formation of a plica verticalis which separates the endolymphatic organ from the otocyst proper. This is probably associated with the rotation of the vesicle proper accompanied by fixation of the tip of the endolymphatic organ. 5) Elongation of the duct by evagination and thinning of the epithelial wall. 6) Expansion of the distal terminus of the duct to form the endolymphatic sac, and, finally, 7) histologic differentiation.

All of these processes are essential to the production of the Ambystoma endolymphatic duct. In other salamanders these processes have varying influence; in one the duct becomes long, in another it is short; in one form the sac is markedly dilated, in another it is only slightly expanded.

It is reasonable to assume that in one animal class a certain process may be dominant, while in another of negligible influence. The endolymphatic organ may be formed in one animal predominantly by the development of a plica verticalis 
of late origin, while in another it is formed through the agency of a rotation of the otocyst. In Oryzias the first process essential to the formation of the duct is lacking, consequently there is no duct. Since subsequent developmental changes are similar, the absence of one process (i.e., the failure of closure of the selachian duct) does not destroy the concept of homology.

In none of the forms so far described is the organic similarity of the tubiform auditory structure, under discussion, too unreal to warrant the name endolymphatic organ. This was the opinion of Hasse (' $73 \mathrm{~b}$ ), who on purely gross relationships proposed the name endolymphatic duct and sac.

\section{Comparison of the endolymphatic organ throughout vertebrates}

Although there are certain characteristics more or less consistently found in the endolymphatic organ of vertebrates, peculiarities are evident in the different groups. In the lampreys (Ketel, '72; Hasse, '73 b, and Retzius, '81 a) two tubular diverticula have been described. One is an almost horizontal tube lying in the upper part of a vertical commissure which nearly separates the vestibule into anterior and posterior parts; the other arises from a narrow vestibular orifice and extends upward to its club-shaped termination in a sulcus in the mesial wall of the ear. Neither tube penetrates the ear capsule. Ayers ('92) and Norris ('96) looked upon both tubes as endolymphatic ducts, making use of this evidence for their view of the phylogenetically heterogeneous origin of the ear. The first-named diverticulum is formed of a low cylindrical epithelium and has a specialized nerve ending. Hasse and Retzius believed this to be the endolymphatic duct; Ketel considered the other diverticulum as the endolymphatic organ. Krause ('06 a), after following the developmental sequence of the duct, agreed with Hasse and Retzius. Plate ('24) was likewise of this opinion. 
In the hagfish (Ketel, '72; Retzius, '81 a), the organ extends as a club-shaped diverticulum into the endocranial cavity, accompanied by a blood vessel. In this form the organ, formed of columnar cells, contains calcium salts.

The endolymphatic organ of selachians and chimerae (Breschet, '38; Hasse, '73 b; Retzius, '78, '81 a ; Portmann, '20) shows a departure from that of all other forms in that it opens directly on the body surface. The duct epithelium is cubical or columnar.

In the ganoid fishes (Cisow, '80; Retzius, '81 a, '81 b) two types of organ have been described. The structure in Acipenser and Calamoichthys, extending from the sacculus to the endocranial cavity where it lies upon the dura, is club-shaped; that of Amia and Lepisosteus is tubular and ends within the otocrane at the level of the superior sinus.

The endolymphatic organ of dipnoan fishes is a club-shaped structure extending from the sacculus to the extradural space. In Neoceratodus (Burne, '13) a large blood vessel extends between the apices of the sacs of the two sides. In Protopterus (Burckhardt, '92) the endolymphatic sacs are expanded structures lying on each side of the medulla. The sac whose surface is thrown into irregular villosities contains numerous otolith crystals. Whiteside ('22) made a point of the similarity of the endolymphatic sac of Protopterus and certain of the Amphibia as indicative of a phylogenetic relationship.

Teleosts, aside from the clupeoid fishes and a few other exceptions (Retzius, '81 a; Tschernoff, '09; Kuhn, '77; Krause,'06 b), have a duct arising from the sacculus and extending along the utriculus with its mesial side adjacent to the dura. The organ does not extend into the endocranial space. Descriptions of the endolymphatic organ are inconsistent regarding those fishes in which the swim bladder has become associated with the ear. Breschet ('38), Hasse ('72, ' $73 \mathrm{c}$ ), and Ridewood ('91) recognized an epicerebral conduit which extends from one ear to the other. Nusbaum ('81), Ridewood ('92), Sidoriak ('99), Nusbaum and Sidoriak ('99), Bridge ('04), Schimkewitsch ('10), and Portmann ('21 a) 
believed that the endolymphatic organ is represented by a transverse subcerebral connection between the sacculi of the two sides, and a posterior blind diverticulum extending from the midpoint of the connection. The epithelium is partly squamous and partly columnar and there are sensory endings on the structure. Tracy ('20) was inclined to believe that neither the epicerebral nor subcerebral connections are anything but thickened meningeal tissue. There is no indication of an endolymphatic organ in Oryzias (Murayama, '27 a), Chloea and Salmo iridis" (Yamamoto, '29).

The endolymphatic organ of the Amphibia may be grouped in three major groups, on the basis of extent and vascularity, all having the same major relations to the sacculus and extradural space. The first group, referred to above as type I, has a small globular non-vascular endolymphatic sac. The next group consists of those forms having an expanded endocranial sac supplied largely by diffuse vessels from the choroid plexus and possibly also from dural vessels (types II, III, and IV), and the last group includes those forms having a sac further expanded into the neural-arch cavities of the vertebrate, the sac being supplied by definitive dural sinuses (types V and VI). The expanded types of the endolymphatic organ are typically filled with calcareous matter; the small globular form of the sac has little or none. In each of these forms the endolymphatic sac is composed of cubical epithelium; the duct is made up of a peculiar columnar ependyma-like epithelium.

In the crocodile (Hasse, '73 e) and alligator (Retzius, '84), the duct, arising from the sacculus, courses between the dura and the bony skull wall to form a pear-shaped sac which extends to the upper surface of the medulla. Hasse found chalk erystals in the sac of a young specimen. A similar structure has been observed in the lizard (Clason, '71; Hasse, '73 b; Sterzi, '09). In the geckos, Platydactylus, Hemidactylus, and Ascalabotes, Wiedersheim ('76) has described

s Salmo has a typical endolymphatic organ, according to Retzius ('81 a). 
a remarkably extended endolymphatic sac, which passes through the extradural space and extends out of the skull and divides into two irregular diverticula, one extending along the roof of the mouth and the other through an aperture in the parietal bone into the region of the neck, where its processes diverge through the lateral cervical musculature. In Ascalabotes the sacs of the two sides fuse, but this fusion is not found in the other geckos. The sac is composed of irregular polygonal flattened epithelial cells. Phisalix ('13) observed the enlarged sac of Gecko verticillatus. The structure is very vascular and is filled with calcium-carbonate crystals, reminding one of the expanded sac in the frog.

In view of the work of Hasse ('73 b), Kuhn ('82), Retzius ('84), Hoffman ('90), and Sterzi ('09) on turtles, and Hasse ('73 d), Kuhn ('82), Retzius ('84), and Hoffman ('90) on snakes, the relations may be described as similar to those of the typical lizards. The extent of the sac in Sphenodon may be realized from the figures of Dendy ('09) (no description) which indicate that the sac is a bulbous structure lying above the choroid plexus.

In Sphenodon, the crocodile, and the turtle the distal end of the club-shaped endolymphatic organ lies over the medulla and abuts on the longitudinal dural sinus. Although this relationship has not been described in the snake and lizard, it may be assumed to exist, judging from the known relations of the dural sinuses. The indications are that the endolymphatic sac of reptiles, except for the expanded extracranial sac of the gecko, is free of calcium in the adult. The epithelium of the structure is cubical.

In birds (Röthig and Brugsch, '02; Sterzi, '09), a part of the club-like endolymphatic organ lies adjacent to the transverse dural sinus. Its shape is similar to that found in reptiles and, as in the reptiles, it lacks calcium in the adult stages. Its epithelium is of the simple columnar type. Portmann ('20 c) failed to find a bulbous sac in the pigeon. Hasse ( $73 \mathrm{~b}$ ) indicated that in birds the endolymphatic sac opened funnelwise into the epicerebral cavity. Retzius ('84) failed 
to confirm this by injecting fluids into the endolymphatic organ.

Hasse ('73 b), who gave the terms endolymphatic duct and sac to the 'aqueductus vestibuli' of the older authors, believed that the cavity of the endolymphatic sac in mammals was in communication, by a fine opening in the dura, with the intradural spaces. This opinion, however, was later abandoned ('81). Although Rudinger ('87) again brought forward this view, the current concept is that the organ is closed.

Several investigators have dealt with the form and relations of the mammalian endolymphatic organ (Boettcher, '69 b; Sterzi, '09; Alexander, '01 b, '24). Streeter ('06, '15, '16), Portmann ('21, '27), Chattellier ('26), and Guild ('28) have studied the endolymphatic sac in man. The organ arises by two small ducts, one from the sacculus and the other from the utriculus. The endolymphatic duct extends to the endolymphatic foramen and through it to form an expanded sac between the two dural layers (ie., between the dura and periosteal lining of the skull), lying in a shallow fossa on the face of the petrosal portion of the temporal bone below the transverse dural sinus. A utriculo-endolymphatic valve, which may close the utricular orifice of the endolymphatie duct, has been described by Bast ('29) for the ear of the foetus and by Anson and Wilson ('29) for the infant and adult human. The endolymphatic organ has been observed in other mammals such as the Echidna (Alexander, '04), the guinea-pig (Sterzi, '09; Portmann, '19; Guild, '27), the hedgehog (Sterzi, '09), the rabbit (Retzius, '84; Sterzi, '09; MoNally, '27), the porcupine (Struthers, '27), the porpoise (Boenninghaus, '04), the dog (Sterzi, '09), the cat (Boettcher, '69 b; Retzius, '84; Sterzi, '09), the sheep (Sterzi, '09; Portmann, '20), the cow (Boettcher, '69 a; Hasse, '73 b; Retzius, '84; Sterzi, '09), the horse (Cohrs, '27; Sterzi, '09), the pig (Hasse, '73 b; Retzius, '84; Sterzi, '09), and the bat (Iwata, '24). The indications are that there is little variation from the type of organ found in man, the sac being a small ovoid vesicle lying in the dura next to the 
transverse sinus and the duct arising from both utriculus and sacculus. ${ }^{4}$

The histological condition of the endolymphatic organ has been described in only a few mammals, most completely in the guinea-pig and man by Guild ('27, '28), where there are three distinct types of epithelia. In the duct proper the epithelium is of the simple squamous type; in the proximal part of the sac the wall is formed of a columnar epithelium lacking a basement membrane and thrown into folds. The distal part of the sac is a thick pavement epithelium. The columnar region is rendered highly vascular by a plexus of vessels leading into the lateral sinus. The studies of other workers on the histology of the organ have indicated the presence of both squamous and cubical cells. In the mammal Guild has demonstrated that the otic fluid contains free cells of leucocytic or phagocytic nature.

No one has demonstrated a nerve supply for the endolymphatic organ, aside from fibers going to the special sensory ending found in the ducts of the lamprey and the clupeoid and cyprinoid fishes. In both these fishes, it is to be remembered that some question has arisen as to the identity of the endolymphatic organ.

In view of the above survey, one point not hitherto recognized becomes apparent. In the higher Amphibia and Amniotes the endolymphatic sac has an intimate relationship with the dural sinus. The sac is typically vascular in lower forms in so far as it is independently supplied with blood vessels or is nestled in the vascular choroid plexus of the fourth ventricle, but definitive dural vessels are not developed below the higher Amphibia. It should be remembered that the dura, probably, first becomes differentiated as a meningeal layer in the Amphibia and in association with this structure dural sinuses are developed. Streeter ('16) has pointed out

\footnotetext{
4 E. F. Hoffman and T. H. Bast have recently indicated that the utriculoendolymphatic valve is present in the monkey, cow, sheep, pig, dog, cat, rabbit, gray squirrel, guinea-pig, rat, and gopher. (Wistar advance abstract of paper appearing in The Anatomieal Record, 1930.)
} 
the intimate connection between the endolymphatic sac and the dural vessels in the human embryo during developmental stages. Although he was primarily concerned with the interrelation of the structures from a functional standpoint, if now beeomes apparent that the relations may be of phylogenetic importance, since a parallelism may be noted in the relations of the dural sinuses of the human embryo, during development, and the dural veins of Amphibia and reptiles as described by Rex ('93), Grosser ('07), and Dendy ('09).

\section{Possible function}

Hasse ('73 b) was the first investigator to become concerned about the function of the endolymphatic organ. $\mathrm{He}$ believed that it had three possible functions in all vertebrates; first, that it secreted otic fluid in the embryo; secondly, that it absorbed cerebrospinal fluid by endosmosis or through pores which Hasse assumed to be present in certain forms, and, thirdly, that the endolymphatic sac served as a reservoir for otic fluid, supplying it to the labyrinth when necessary. Although Hasse ('81) later abandoned the idea of openings in the endolymphatic sac, he still retained the idea of the endolymphatic organ as an organ for replenishing otic fluid, saying:

Der Liquor endolymphaticus findet seinen Abflussweg durch die Arachnoidealscheide des Acusticus in den Subarachnoidealraum und erneuert sich vielleicht auf dem Wege der Diffusion durch den Ductus endolymphaticus und vor allen Dingen durch dessen Sacculus aus den epi- oder endoduralen serösen Bahnén.

Rudinger ('87), still believing that the endolymphatic sac opened into the endocranial space, maintained that the endolymphatic organ was a canal of exit for otic fluid.

Key and Retzius ('75) demonstrated by injecting substances into the endocranial spaces that there was no communication between the intrameningeal spaces and the otocrane cavities, either otic or periotic. That this is a usual condition is evident from similar findings in the frog (Harrison, '02). 
La Reau ('26) has revived the theory of Hasse which regards the endolymphatic sac as a reservoir for otic fluid. When the otic-fluid pressure within the labyrinth becomes high, the fluid flows into the endolymphatic sac, which opens bellows-like to receive it. This theory overlooks the fact that the endolymphatic sac is virtually embedded in endocranial fluid whose incompressibility would render it little liable to expansion. Keibel ('15) and Streeter ('06) looked favorably on this view.

When the open end of the endolymphatic duct of a shark is sealed by wax or cautery, the fish develops symptoms of equilibratory disturbance. Portmann ('21 d) assumed that increased pressure due to disturbance of normal duct function is responsible for the equilibratory upset.

Guild ('27 b) measured the length of time taken for fluids to flow away from a point of injection in the cochlear duct in the guinea-pig. He found a definite circulation to exist. Otic fluid which is-

formed by the stria vaseularis, flows toward the basal end of the cochlear duct and through the eanalis reuniens into the sacculus and from this through the ductus endolymphaticus into the saccus endolymphaticus, and leaves the membranous labyrinth by passing through the wall of the pars intermedia of the saccus into the numerous small blood vessels of this region.

Guild thus showed that otic fluid passes directly through the endolymphatic-sac wall.

Under the assumption of a circulation of otic fluid, it is maintained by the writer that such a theory as Guild's for the release of otic fluid is the only one, yet suggested, that is tenable on the basis of labyrinthine structure. ${ }^{5}$

The delicate otic membranes maintain their relations largely through the influence of an endosmotic pressure. This pressure is maintained by the saline and serum content of the otic fluid which is greater than in either the periotic or

\footnotetext{
s The remarks which follow apply specifically to the labyrinth of Amphibia, but it is assumed, on the basis of structural similarity of other vertebrates, that the conclusions will not be restricted to the amphibians alone.
} 
cerebrospinal fluid, as evidenced by the coagulum produced by fixing agents containing heavy metals and by the visible calcium content. Fluid is thus absorbed into the otic spaces from the periotic fluid, blood vessels of the periotic tissues, or from the cerebrospinal fluid. In the Amphibia there is no vascularized epithelium comparable to the stria vascularis of the mammalian eochlea, so it is highly probable that otic fluid does not arise from any specific part of the labyrinth. The presence of very thin epithelia, the tympanal areas, on the sacculus, pars neglecta, and pars basilaris makes it probable that fluid is absorbed through these membranes by osmosis rather than through the thick lamina propria found elsewhere around the labyrinth. It is likewise conceivable that fluid might pass from the endocranial cavity into the endolymphatic organ. Its epithelium, however, is typically cubical-the only cubical epithelium of the labyrinth not covered by a dense lamina propria. A free cubical epithelium such as this may be regarded as a secreting membrane. ${ }^{6}$

It must be assumed from the structure of the labyrinth that fluid gains entrance to the otic spaces from the periotic spaces by way of the tympanal areas and that the only method of fluid egress from the otic cavities is by active secreting action of the endolymphatic-sac epithelium into the cerebrospinal fluid or into the endocranial blood vessels.

The endolymphatic organ in Amphibia undoubtedly has secondary functions. The expanded endolymphatic sac probably functions as a menix (Sterzi, '99). The necessity, however, of such a protection for the brain in one form and not in another is not easy to explain. After observing that the endolymphatic sac in the frog contained various masses of calcium at different times, Gaupp ('97) believed that the calcium of the endolymphatic sac had a definite relation to metabolism, possibly in connection with bone growth. Whiteside ('22, thesis) examined over a hundred frogs and found that under conditions of inanition the amount of calcium

- Similar epithelia are found in the kidney tubules, thyroid vesicles, and elsewhere in the animal body. 
within the sac decreased. Herter ('22) experimented on adult frogs by removing bony segments of the femur or himerus. Complete calcification occurred in about two months and no change was observed in the contents of the sac. Since frogs were not kept under starvation conditions, the results of these experiments are not significant.

\section{SUMMARY}

1. An extensive survey of the anatomy of the endolymphatic organ has been made on thirty-four species of amphibians.

2. The histological structure is similar throughout the group, the sac being formed of cubical cells, which grade into the columnar cells of the duct. A part or the whole of the duct is formed of peculiar 'ependyma-like' cells.

3 . The organ typically arises from the sacculus, extends to the endolymphatic foramen, by which it enters the endocranial cavity. Here the sac-like expansion of the organ lies in the extradural space.

4. Six morphological types of endolymphatic organ may be recognized in the Amphibia: I) A simple club-like appendage (in Necturus, Cryptobranchus, Amphiuma, Siren, Rhyacotriton, Gyrinophilus, Eurycea, Desmognathus, Hemidactylium, Stereochilus, Typhlotriton, Manculus, and Typhlomolge. II) An endolymphatic organ which is expanded within the endocranial cavity and in which the two sacs do not fuse (in Salamandra, Triton, and Triturus). III) An organ with much the same relations as found in the salamandrids, but with the sac having a marked constriction anterior to the junction of the duct (in Plethodon, Batrachoseps, and Aneides). IV) An organ formed of large fused sacs (Ambystoma). V) A structure, composed of fused endolymphatic sacs, which consists of a ring around the brain and a large dorsal posterior process which extends into the vertebral canal (Rana and Xenopus). VI) A structure similar to the above, but with an anterior intercerebral process (Bufo, Hyla, Acris, Pseudacris, Scaphiopus). 
5. The development of the endolymphatic organ of types I, II, IV, and VI has been followed. The structure in each case may be considered to have reached its definitive condition at the time of metamorphosis.

6 . The types of sac structure cannot be readily correlated with any habit of the animals possessing them.

7. A discussion is given of the homology, comparative morphology, and function of the organ throughout vertebrates.

\section{LITERATURE CITED}

Arexander, G. 1901 a Zur Entwicklung des Ductus endolymphaticus. Arch. f. Ohren-, Nasen- u. Kehlkopfh., Bd. 52.

$1901 \mathrm{~b}$ Ueber Entwicklung und Bau der Pars inferior labyrinthi der höheren Säugethiere. Ein Beitrag zur Morphologie des Ohrlabyrinthes. Denkschr. Akad. Wiss. Wien, math.-nat. Cl., Bd. 70. 1904 Entwicklung und Bau des inneren Gehörorganes von Echidna aculeata. Ein Beitrag zur Morphologie des Wirbelthierohres. (Semon Zool. Forsehungsreisen in Australien und dem Malayischen Archipel., Bd. 3, T. 2). Denkschr. med.-nat. Ges. Jena, Bd. 6, Heft 2.

1924 Zur Anatomie des Ductus endolymphaticus. Ztschr. f. Hals-, Nasen- u, Ohrenh., Bd. 9.

Anson, B. J., AND J. G. WILson' 1929 The utricular fold in the adult human ear. Anat. Ree, vol. 43.

AYERS, H. 1892 Vertebrate cephalogenesis. A contribution to the morphology of the vertebrate ear, with a reconsideration of its functions. Jour. Morph., vol. 6.

BALFour, F. 1880 Handbook of comparative embryology. London.

BAst, T. H. 1928 The utriculo-endolymphatic valve. Anat. Rec., vol. 39 (abstract) and vol. 40 .

Boenninghate, G. 1904 Das Ohr des Zahnwales, zugleich ein Beitrag zur Theorie der Schalleitung. Eine biologische Studie. Zool. Jahrb., Abt. Morph., Bd. 19.

Boetrcher, A. 1869 a Über den Aquaeductus vestibuli bei Katzen und Menschen. Arch. f. Anat. u. Physiol.

$1869 \mathrm{~b}$ Über Entwickelung und Bau des Gehörlabyrinthes nach Untersuchungen an Säugetieren. Verhandl. d. Kaiserl. Leop. Carol. deutsch. Akad. der Naturforsch., Bd. 35.

Breschet, M. G. 1838 Recherches anatomiques et physiologiques sur l'organe de l'ouie des poissons. Mém. Acad. Roy. des sei. de l'inst. de France, T. 15.

Bridge, T. W. 1904 Fishes. Cambridge Nat. Hist., vol. 7.

BurckhardT, R. 1892 Das Centralnervensystem von Protopterus annectens. Berlin.

Bdrne, R. H. 1913 Note on the membranous labyrinth of Neoceratodus forsteri. Anat. Anz., Bd. 43. 
Calori, L. 1850 Sulla anatomia dell'Axoloti. Mem. dell'Accad. delle Sc. dell'Ist. di Bologna, vol. 3, no. 3.

Carus, C. G. 1827 An introduction to the comparative anatomy of animals, vol. 1. London.

Chamberlain, C. J. 1915 Methods in plant histology. Univ. of Chicago Press, Chicago.

Chattellier, H. P. 1926 Évolution embryologique de l'appareil endolymphatique et du cloisonnement utriculo-sacculaire chez l'homme. Arch. Anat., Histol., et Embr., T. 5.

Cisow, A. 1880 Ueber das Gehörorgan der Ganoiden. Arch. f. mikr. Anat., Bd. 18.

Clason, E. 1871 Die Morphologie des Gehörorgans der Fidechsen. Anat. Stud. (Hasse), Bd. 1, Hft. 2: 8 .

CoaGI, A, 1890 a Über die sogenannten Kalksäckehen an den Spinalganglien des Frosches und ihre Beziehungen zum Ductus endolymphaticus. Anat. Anz., Bd. 5.

$1890 \mathrm{~b}$ I sacehetti caleari ganglionari e l'acquedotto del vestibolo nelle rane. Atti d. r. Accad. d. Lincei, Mem. Se. fis. Math. Nat., vol. 6 , ser. 4 .

CoHrs, P. 1928 Studien zur normalen und pathologischen Anatomie und Histologie des inneren Gehörorganes vom Pferde (Equus caballus). Areh. f. Ohren-, Nasen- u. Kehlkopfh., Bd. 1.18, Hft. 1.

Dendy, A. 1909 The intracranial vaseular system of Sphenodon. Phil. Tr. Roy. Soc. London, (B), vol. 200.

Fineman, G. 1915 Beiträge zur Kenntnis der Entwicklung des Ductus endoIymphaticus bei dem Menschen und einigen Wirbeltieren. Anat. Hefte, Bd. 53.

Fleissig, J. 1903 Die Entwicklung des Geckolabyrinthes. (Ein Beitrag zur Entwicklung des Reptilienlabyrinthes.) Anat. Hefte, Bd. 37.

GAGE, S. P. 1893 The brain of Diemyetylus viridescens, from larval to adult life and comparisons with the brain of Amia and Petromyzon. The Wilder Quarter Century Book, 1868-1893. Comstock, Ithaca,

GaUPP, E. 1897-1904 A. Ecker und R. Wiedersheim's Anatomie des Frosches. F. Vieweg und Sohn, Braunschweig.

Grosser, O. 1907 Die Elemente des Kopfvenensystem der Wirbeltiere. Verh. d. anat. Gesell., Bd. 21.

GuiLd, S. R. 1927 a Observations on the structure and normal content of the ductus and saccus endolymphaticus in the guinea-pig. Am. Jour. Anat., vol. 39 , no. 1 .

$1927 \mathrm{~b}$ The circulation of endolymph. Am. Jour. Anat., vol. 39, no. 1 .

1928 The duetus and saccus endolymphaticus in man. Anat. Rec., vol. 38 .

Harrison, H. S. 1902 On the perilymphatic spaces in the amphibian ear. Internat. Monatsehr. f. Anat. u. Phys., Bd. 19.

HAsse, C. 1872 Das Gehörorgan der Fische. Anat. Stud. (Hasse), Bd. 1, Hft. $3: 10$. 
HASSE, C. 1873 a Ueber den Bau des Gehörorgan von Siredon pisciformis und über die vergleichende Anatomie des Kiefersuspensorium. Anat. Stud. (Hasse), Bd. 1, Hft. 3: 15.

$1873 \mathrm{~b}$ Die Lymphbahnen des innern Ohres d. Wirbeltiere. Anat. Stud. (Hasse), Bd. 1, Hft. 4: 19.

1873 e Die Morphologie des Gehörorgans von Coluber natrix. Anat. Stud. (Hasse), Bd. 1, Hft. 4: 16.

1873 d Das Gehörorgan der Crocodile nebst weiteren vergleichend anatomischen Bemerkungen über des mittlere Ohr der Wirbelthiere und dessen Annexa. Anat. Stud. (Hasse), Bd. 1, Hft. 4: 17.

1881 Bemerkungen über die Lymphbahnen des inneren Ohres. Arch. f. Ohrenh., Bd. 17.

HellmanN 1898 Die Entwicklung des Labyrinths bei Torpedo ocellata. Verhandl. der Deutsch. Otol. Gesellsch. Jena.

HeRTER, K. 1922 Ein Beitrag zur Kalksackproblem der Frösche. Anat. Anz., Bd. 55 .

HochstetTeR, F. 1916 Bemerkung zu dem Artikel F. Keibels: "Der Ductus endolymphaticus (Recessus labyrinthi) bei Sehildkröten.' Anat. Anz., Bd. 49.

HoFmanN, C. K. 1890 a Reptilien. II. Eidechsen u. Wasserechsen. Bronn's Klassen u. Ordnungen des Thier-Reichs, Bd. 6, Hft. 3.

$1890 \mathrm{~b}$ III. Schlangen und Entwicklungsgeschichte der Reptilien. Bronn's Klassen und Ordnungen des Thier-Reichs, Bd. 6, Hft. 3.

IwatA, N. 1924 Über das Labyrinth der Fledermaus. Aichi Jour. Exp. Med., vol. 1 , no. 4.

KAAN, H. 1926 Experiments on the development of the ear in Amblystoma punctatum. Jour. Exp. Zoöl., vol. 46, no. 1.

KEIBEL, F. 1899 Ueber die Entwickelung des Labyrinthanhanges (Recessus labyrinthi oder Duetus endolymphat.). Anat. Anz., vol. 16.

1915 Der Ductus endolymphaticus (Recessus labyrinthi) bei Schildkröten. Anat. Anz., Bd. 48.

Kerr, GrahaM 1919 Textbook of embryology. Vol. 2. Vertebrata. Macmillan Co., London.

KETEL, H. 1872 Ueber das Gehörorgan der Cyclostomen. Anat. Stud. (Hasse), Bd. 1, Hft. $3: 11$.

Key, A., AND G. ReTzrus 1875 Die Verbindungen der Seheidenräume des Acusticus und der serösen Räume des Gehörlabyrinthes mit den serösen Räumen der nervösen Centralorgane. Stud. in d. Anat. d. Nervensystems und d. Bindegewebes, Hft. 7. Stockholm.

Kingsbury, B. F, 1895 On the brain of Necturus maculatus. Jour. Comp. Neur., vol. 5 .

Krause, R. 1901 Die Entwickelung des Aquaeduetus vestibuli u. Duetus endolymphaticus. Anat. Anz., Bd. 19. 1906 a Das Gehörorgan der Petromyzonten. Verhandl, anat, Gesellsch., Bd. 22.

$1906 \mathrm{~b}$ Entwicklungsgeschichte des Gehörorgans. Handb. vergl. u. exp. EntwickIungslehre d. Wirbelthiere, heraus. O. Hertwig, Bd. 2, Hft. 2. 
KUHN 1877 Untersuchungen über das häutige Labyrinth der Knochenfische. Arch. f. mikr. Anat., Bd. 14.

1882 Beiträge zur Anatomie des Gehörorgans. Abtheil. 3. Ueber das häutige Labyrinth der Reptilien. Areh. f. mikr. Anat., Bd. 20.

v. KUPFFER, C. 1900 Studien zur vergleichenden Entwicklungsgeschichte des Kopfes der Kranioten. Zur Kopfentwicklung von Bdellostoma, Hft. 4. München u. Leipzig.

LANDACRE, F. L. 1926 The primitive lines of Amblystoma jeffersonianum. Jour. Comp. Neur., vol. 40.

1927 The differentiation of the preauditory and postauditory primitive lines into preauditory and postauditory placodes, lateralis ganglia, and migratory lateral-line placodes in Amblystoma jeffersonianum. Jour. Comp. Neur., vol. 44.

LA REAU, H. G. 1926 Saceus endolymphaticus and its relation to labyrinthine muscle tonus. Ann. Otol., Rhinol., and Laryngol., vol. 35.

v. Lenhossek, M. 1886 Untersuchungen über die Spinalganglien des Frosches. Arch. mikr. Anat., Bd. 26, Hft. 3.

MCNalus, W. J. 1927 Puncture of the round window membrane: Experiments on the saccus endolymphaticus in the rabbit. Arch. of Otolaryngol., vol. 5 .

Michl, RUdolPH 1925 Über die Entwicklung des Gehörlabyrinthes bei Rana temporaria. Spisy lékărské fakulty Mosorykovy univ, v. Bruě, vol. 3, no. 7 .

Mitrophanow, P. 1890 Über die erste Anlage des Gehörorgans bei niederen Wirbelthieren. Biol. Zentralbl., Bd. 10.

1893 Étude embryogénique sur les sélaciens. Arch. de zool. exper. et gén., série 3, T. 1, no. 2.

Murayama, T. 1927 Die Entwickelung des häutigen Labyrinthes des Knochenfisches (Oryzias latipes). Folia Anat. Japon., Bd. 5, Hft. 4. 1928 Die Entwickelungsgeschichte des häutigen Labyrinthes von Megalobatrachus japonicus. Folia Anat. Japon., Bd. 6, Hft. 3.

NetTo, Friedrich 1898 Die Entwicklung des Gehörorgans beim Axolotl. Ein Beitrag zur Embryologie des Amphibienohrs. Inaug. Diss., Berlin.

NoBLE, G. K. 1927 The value of life history data in the study of the evolution of the Amphibia. Ann. N. Y. Acad. Sci., vol. 5.

Norrus, H. W. 1892 Studies on the development of the ear in Amblystoma. I. Development of the auditory vesicle. Jour. Morph., vol. 7 .

1894 The development of auditory vesicle in Necturus. Proc. Iowa Acad. Sci., vol. 1.

1896 Homologies of the Cyclostome ear. Proc. Iowa Acad. Sci., vol. 3 .

1901 The ductus endolymphaticus in axolotl. Anat. Anz., Bd. 19.

v. Noorder, C. 1883 Die Entwickelung des Labyrinthes bei Knochenfischen. Areh. f. Anat. u. Physiol., Anat. Abt.

Nusbadm, J. 1881 Über das anatomisehe Verhältnis zwisehen dem Gehörorgane und der Sehwimmblase bei den Cyprinoiden. Zool. Anz, Bd. 4.

Nusbaum, J., UND S. Sidoriak 1899 Das anatomische Verhältnis zwischen dem Gehörorgane und der Schwimmblase bei dem Schlammbeisser (Cobitis fossilis). Anat. Anz., Bd. 16. 
Oкаліма, K. 1906 Zur Anatomie des inneren Gehörorgans von Cryptobranchus japonicus. Anat. Hefte, Bd. 32.

1910 Untersuchungen über die Sinnesorgane von Onychodactylus. Ztsehr. f. wissensch. Zool., Bd. 94.

1911 Die Entwickelung des Gehörorgans von Hynobius. Anat. Hefte, Bd. 45.

Perovic, D. 1914 Die Entwicklung des häutigen Labyrinthes von Emys lutaria. Verhandl. d. Gesellsch. deutsch. Nat. Ärzte Vers., Bd. 85, Hft. 2.

Perovic, D., AND O. AUs' 1915 Zur Entwicklungsgeschichte des Ductus endolymphaticus beim Menschen. Anat. Hefte, Bd. 52.

Peter, K. 1901 Der Schluss des Ohrgrübchens der Eidechse. Arch. f. Ohrenh., Bd. 51.

Phissarix, Mme. 1913 Hypertrophie kystique du sae endolymphatique chez le Gecko verticillatus. Bull. du Mus. Nat. d'histoire Nat., T. 19.

Plate, I. 1924 Allgemeine Zoologie und Abstammungslehre. II. Teil. Die Sinnesorgane der Tiere. Kap. VI. Die statoakustischen Organe der Wirbeltiere.

Plowman, A. B. 1904 The celloidin method with hard tissues. Bot. Gaz., vol. 37 .

PoLI, C. 1897 Zur Entwickelung der Gehörblase bei den Wirbeltieren. Arch. mikr. Anat., Bd. 48, H.ft. 4.

Portmann, G. 1919 Recherches sur le sac et le canal endolymphatique du Cobaye. Compt. rend. Soc. de biol., T. 82.

1920 a L'organe endolymphatique des Selaciens. Compt. rend. Soc. de biol., T. 83 .

$1920 \mathrm{~b}$ Recherches sur le sac et le canal endolymphatique du chien. Compt. rend. Soc. de biol., T. 83.

1920 e Recherches sur le sae et le canal endolymphatique. Sac et canal endolymphatique du Pigeon. Compt. rend. Soe. de Biol., T. 83.

1921 a Organe endolymphatique de quelques Teleosteens. Compt. rend. Soc. de biol., T. 84 .

$1921 \mathrm{~b}$ Recherches sur le sac et le canal endolymphatique chez le foetus humain et l'enfant. Compt. rend. Soc. de biol., T. 84 .

$1921 \mathrm{c}$ Organe endolymphatique des Batraciens. Compt. rend. Soc. de biol., T. 84 .

1921 d Recherches sur la physiologie du sac et du canal endolymphatique. Valeur fonctionnelle de l'organe endolymphatique des Selaciens. Compt. rend. Soc. de biol., T. 85.

1927 Recherches sur le sac endolymphatique. Resultats et applications chirurgicales. Acta Oto-Laryngol., T. 11, no. 1.

Profissming, G. 1924 Zellenzahl u. Zellgrösse im Labyrinthorgan der Tritonen, nebst anderen damit zusammenhängenden Fragen. Zool. Jahrb., Bd. 41.

RaNzio, Silvio 1924 La chiusura dell'otocisti, lo sviluppo del ductus endolymphaticus (o recessus labyrinthi ovvero aquaeductus vestibuli) e la sua omologia nella serie dei vertebrati. Nota prev. (Istit. di Zool., Univ. Roma.) Atti d. R. Acead. dei Lincei, rendiconti, I. Sem., vol. 33 , no. 11 . 
RE'Tzius, G. 1878 Zur Kenntniss von dem membranösen Gehörlabyrinth bei den Knorpelfischen. Areh. f. Anat. u. Physiol., Anat. Abt. 1881 a Das Gelı̈rorgan der Wirbeltiere. 1. Das Gehörorgan der Fische und Amphibien. Stockholm.

$1881 \mathrm{~b}$ Das membranöse Gehörorgan von Polypterus bichir und Calamoichthys calabarius. Biol. Untersuch., Bd. 1 (Retzius). Stockholm.

1884 Das Gehörorgan der Reptilien, Vögel und Säugetiere. Stockholm.

Rex, Hugo 1893 Beiträge zur Morphologie der Hirnvenen der Amphibien. Morph. Jahrb., Bd. 19.

RIDEwoon, W. G. 1891 The air bladder and ear of British clupeoid fishes. Jour. Anat. and Physiol., vol. 26.

Röthig, P., UND T. Bruasch 1901 Die Entwickelung des Labyrinthes beim Huhn. Arch, f. mikr. Anat, Bd. 59.

Rudinger, N. 1887 Über die Abflusskanäle der Endolymphe des inneren Ohres. Sitzungsb. d. k. b. Akademie der Wissensch. zu München, math.physik. Klasse, Bd. 17.

Schimkewitsch, W. 1910 Lehrb. d. vergleich. Anat. d. Wirbeltiere. Stuttgart.

Sidoriak, S. 1898 Ein Beitrag zur Entwiekelungsgesclichte des endolymphatischen Apparats der Fische. Anat. Anz., Bd. 15.

Strerzi, G. 1899 Rückenmarkshüllen der selwanzlosen Amphibien. Anat. Anz., Bd. 16.

1900-1901 Ricerche intorno all'anatomia comparata ed all'ontogenesi delle meningi e considerazioni sulla filogenesi. Atti d. r. Inst. Veneto di Sei., Let. ed Arti, vol. 60, no. 2.

1902 Recherches sur l'anatomie comparée et sur I'ontogénèse des menenges. Areh. ital. d. biol., T. 37.

1909 Il saceo endolinfatico. Ricerche anatomiche ed embriologiche. Morph. Jahrb., Bd. 39.

Streeter, Geo. L. 1906 Development of membranous labyrinth and acoustic ganglion in the human embryo. Am. Jour. Anat., vol. 5.

1915 The development of the venous sinuses of the dura mater in the human embryo. Am. Jour. Anat., vol. 18.

1916 The vaseular drainage of the endolymphatic sac and its topographical relation to the transverse sinus in the human embryo. Am. Jour. Anat., vol. 19.

1918 The histogenesis and growth of the otic capsule and its contained periotic tissue-spaces in the human embryo. Contrib. to Embryol. no. 20, Carn. Inst. of Washington, vol. 7, no. 20.

Struthers, P. H. 1927 The prenatal skull of the Canadian poreupine (Erethizon dorsatus). Jour. Morph. and Physiol., vol. 44, no. 2.

Tracy, H. C. 1920 The clupeoid cranium in its relation to the swimbladder diverticulum and the membranous labyrinth. Jour. Morph., vol. 33 .

TschernofF, N. D. 1909 Ueber den Bau des Gehörorgans von Exocoetus. Anat. Anz., Bd. 34. 
Wenig, J. 1912 Die Entwickelung des Ductus endolymphaticus bei den Knochenfischen. Anat. Anz., Bd. 38.

1913 Untersuchungen über die Entwicklung der Gehörorgane der Anamnia. Morph. Jahrb., Bd. 45.

Whiteside, B. 1922 Development of the endolymphatic sac in the frog. Am. Jour. Anat., vol. 30, no. 2 (also thesis, Univ. Zurich).

Wiedersheim, R. 1876 Zur Anatomie und Physiologie des Phyllodactylus europaeus mit besonderen Berücksichtigung des Aquaeductus vestibuli der Aseoloboten im Allgemeinen. Morph. Jahrb., Bd. 1.

YAMAMOTo, T. 1929 Morphologic studies on the labyrinth of the freslt-water bony fishes. Folia Anat. Jap., Bd. 7, Httt. 4.

\section{PLATE 1}

\section{EXPLANATION OF FIGURES}

2 Transverse section through the otoeyst of an 11-mm. Necturus, showing the primordium of the endolymphatic organ $(E) . \times 46$.

3 Graphic reconstruction of a portion of the labyrinth of an 18-mm. Necturus, showing the further development of the endolymphatic organ. $\times 46$.

4 Same, of a $20-\mathrm{mm}$. speeimen. $\times 46$.

5 Same, of a $40-\mathrm{mm}$. specimen. $\times 46$.

6 Longitudinal section through the endolymphatic organ of an adult Necturus, showing the histologie structure of the duct and sac. $\times 62$.

7 Transverse section through the saccular mouth of the endolymplatic duet. $\times 70$. 

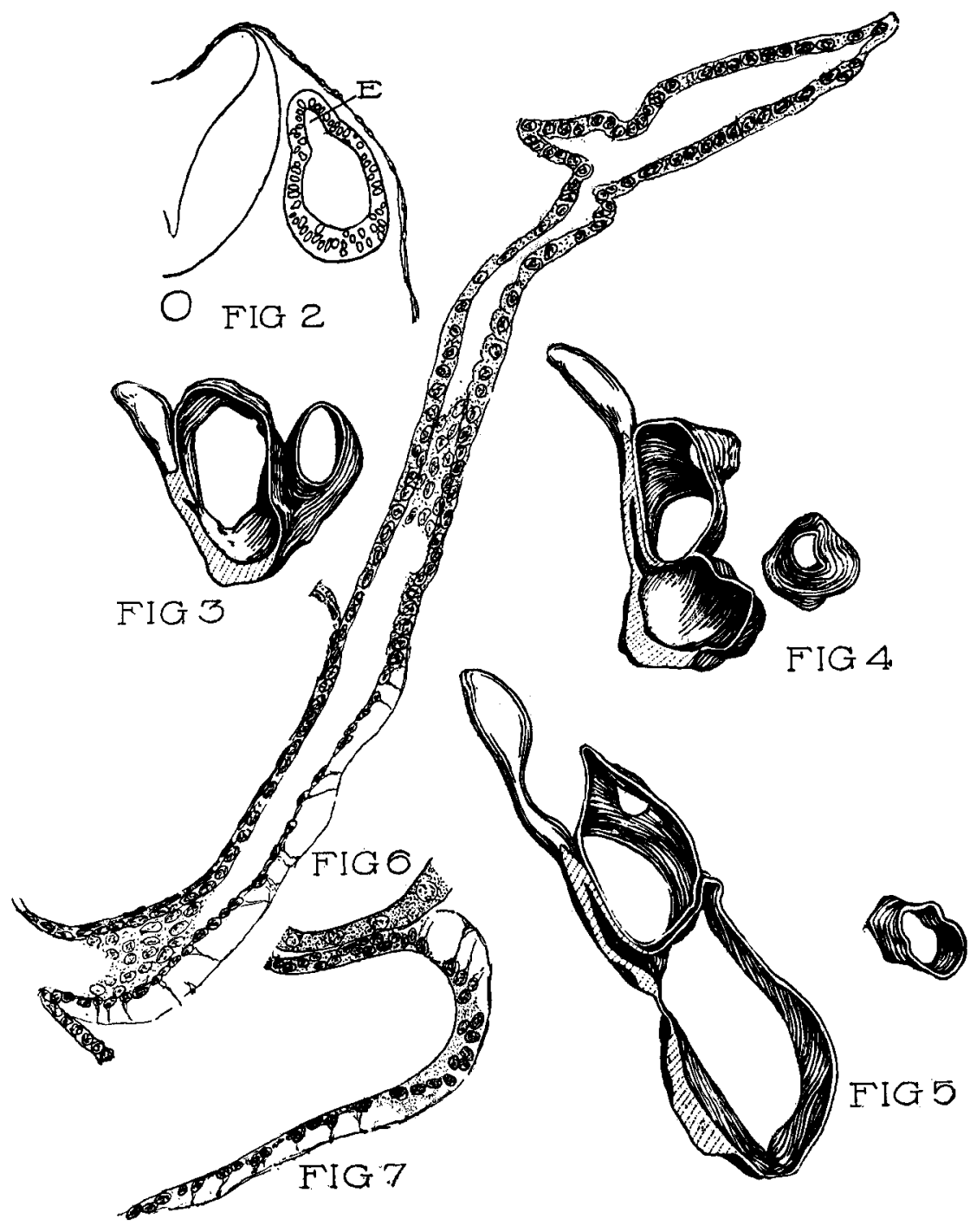


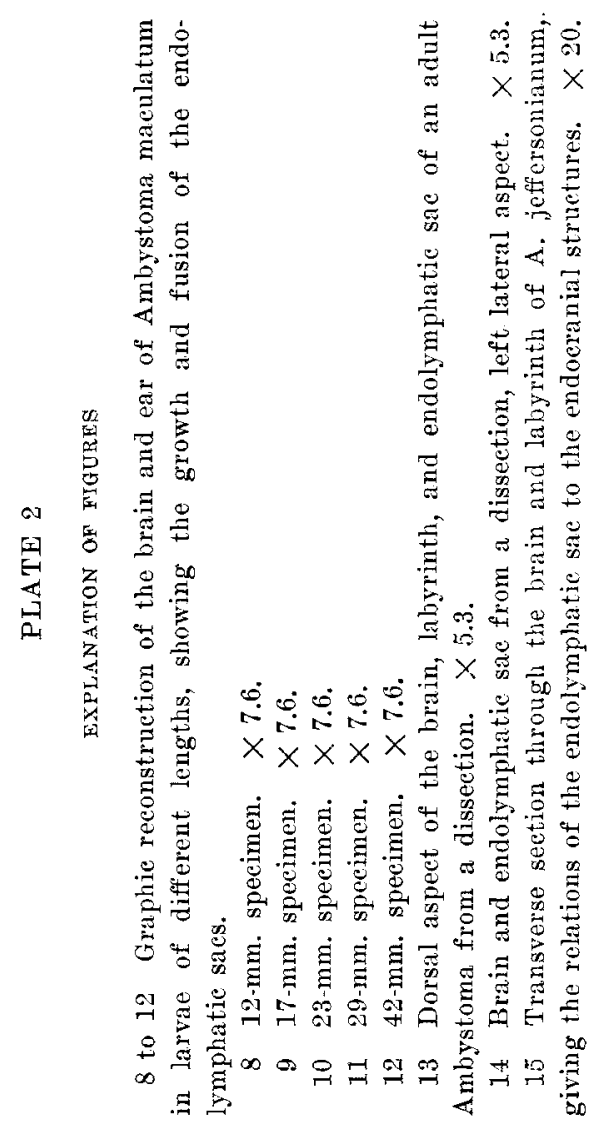




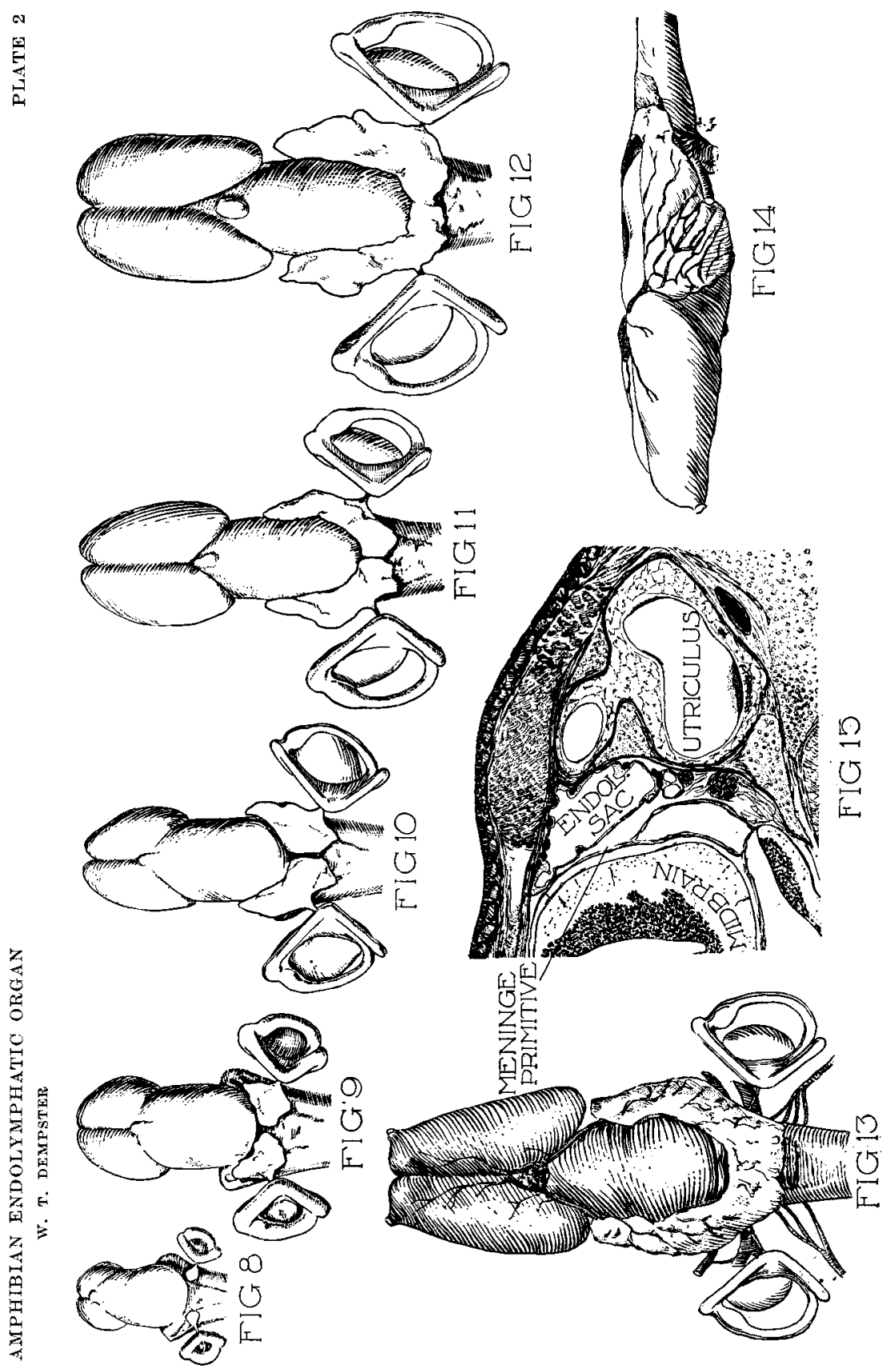


PLATE 3

EXPLANATION OF FIGURES

16 Dorsal aspect of a reconstruction of the brain and ear of Salamandra atra, giving the relations of the endolymphatic organ. $\times 10.5$.

17 Histologic strueture of the endolymphatie duct of Salamandra atra as seen in a longitudinal section. $\times 85$.

18 Transverse section through the endolymphatic duet of Salamandra atra. $\times 234$.

19 A transverse section through the endolymphatic sacs of the two sides which shows them touching, but not fused. $\times 234$.

20 Section through the endolymphatic sac, showing the relation of the epithelium to the blood vessels $(B F), \times 85$.

21 Longitudinal section through the endolymphatic organ of a $12.5-\mathrm{mm}$. Salamandra atra, $\times 85$.

22 Reconstruction of the labyrinth of a $12.5-\mathrm{mm}$. Salamandra atra as seen from the posterior aspect. $\times 32$.

23 Dorsal aspect of a reconstruction of the labyrinth of a $19-\mathrm{mm}$. Salamandra atra, showing the expanding endolymphatic sac. $\times 32$.

24 Dorsal aspect of a reconstruetion of the labyrinth of a $25-\mathrm{mm}$. Salamandra atra, $\times 32$. 


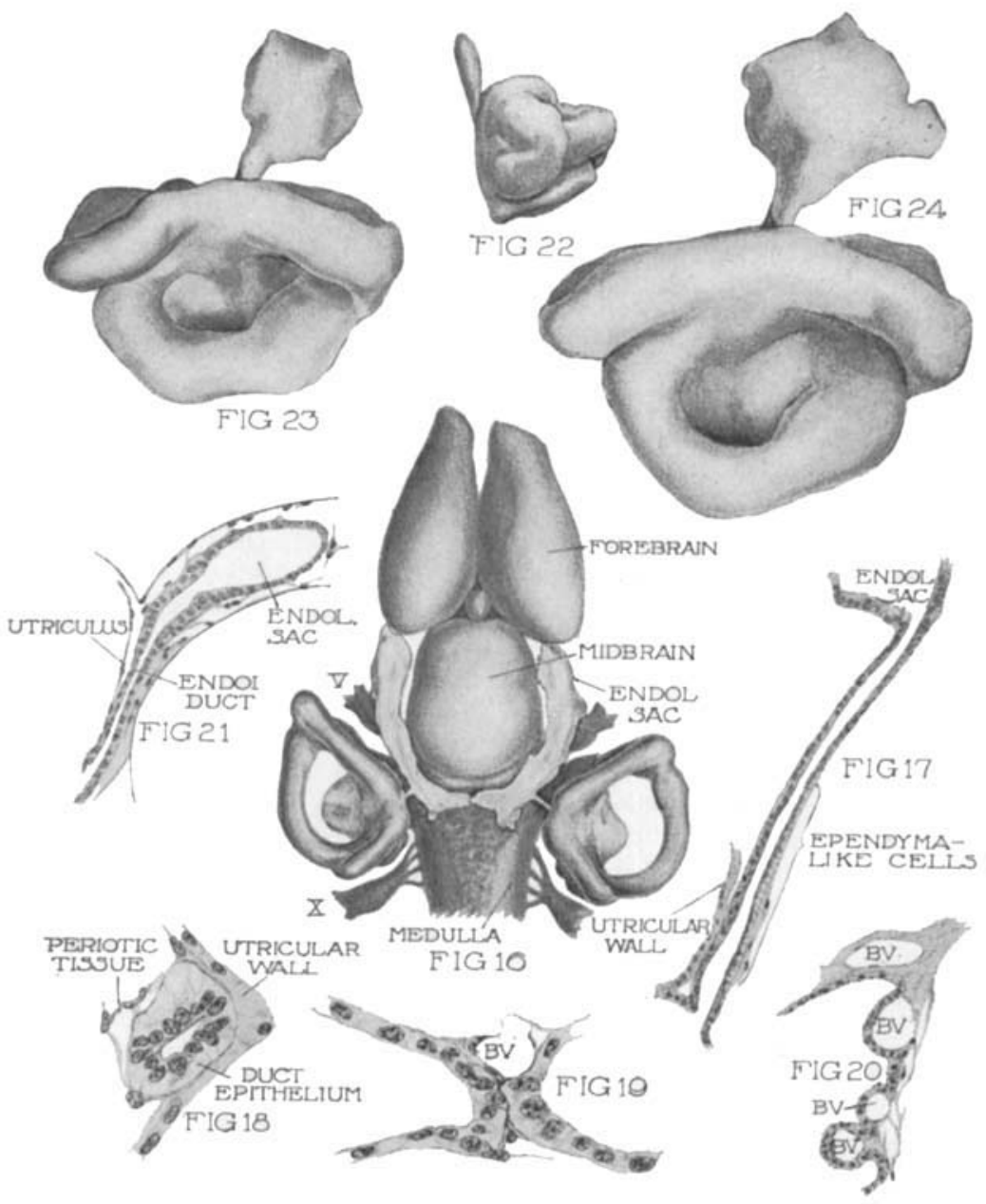


W. T. DEMPSTER

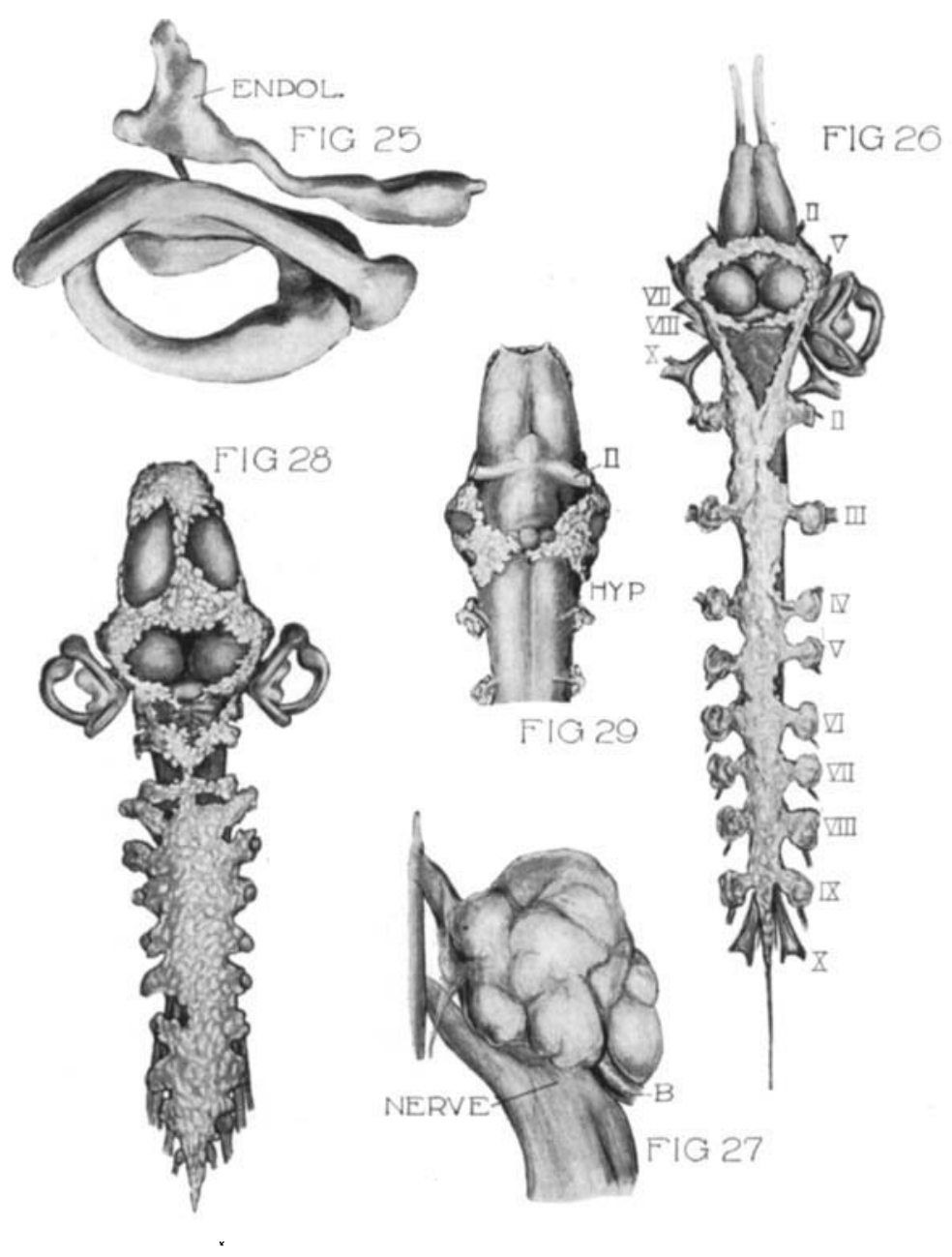

25 Dorsal aspect of a reconstruction of the right labyrinth of Plethodon glutinosus, showing the endolymphatic organ $(E N D O L) . \times 24$.

26 Dorsal aspect of the brain, cord, and labyrinth of Rana catesbeiana, giving in particular the relations of the endolymphatic sac. $\times 1.5$.

27 Dorsal aspect of a reconstruction of a 'chalk sac' of Rana pipiens. $\times 35$.

28 Dorsal aspect of a reconstruction of the brain, cord, and ear of Bufo americanus, showing the relation of the endolymphatic sac. $\times 2.4$.

29 Ventral aspect of the brain of Bufo americanus, showing the relation of the endolymphatic sae to the hypophysis $(H Y P) . \times 2.4$. 